\title{
Ownership, Compensation and Board Diversity as Innovation Drivers: A Comparison of U.S. and Canadian Firms
}

\author{
Gamal Atallah ${ }^{1}$ \\ Claudia De Fuentes ${ }^{2}$ \\ Christine A. Panasian ${ }^{3}$
}

March 2020

\footnotetext{
${ }^{1}$ Department of Economics, University of Ottawa; 120 University Private, Ottawa, Ontario, Canada, K1N 6N5; e-mail: gatallah@uottawa.ca

${ }^{2}$ Department of Management, Sobey School of Business, Saint Mary’s University; 923 Robie Street , Halifax, Nova Scotia, Canada, B3H 3C3; e-mail: claudia.defuentes@smu.ca

${ }^{3}$ Department of Finance, Information Systems and Management Science, Sobey School of Business, Saint Mary's University; ; 923 Robie Street , Halifax, Nova Scotia, Canada, B3H 3C3; e-mail: christine.panasian@smu.ca
} 


\begin{abstract}
Using a large sample of North American firms, from 1999 to 2016, we investigate the effect of corporate governance structures, specifically ownership, board characteristics, and executive compensation contracts on innovation intensity and output. We consider both $R \& D$ expenditures and patents as innovation proxies and evaluate consequences of the economic downturns of 2000 and 2008. We find that $R \& D$ investment increases with ownership by institutional blockholders and with the number of institutional owners, confirming the key role institutions play in innovation activities of firms. We observe higher R\&D levels for firms with more independent boards, more females board members and more outside directorships held by directors. We report that firms with CEO/chair of the board duality have lower $R \& D$ intensity, as do firms with higher ownership by directors and with a higher mean board age. Innovation is negatively related to CEO salary levels, but positively related to the ratio of incentives to total compensation, confirming that incentives contribute to aligning shareholders and management interests, which leads to better long-term decisions. However, those incentives reduce the number of patents. We do not find any systematic changes in $R \& D$ for the 2000 recession, however there is an increase for the 2008 financial crisis.
\end{abstract}

Key words : Corporate Governance, Corporate Finance and Governance, Innovation, R\&D investment, Canada, United States.

JEL classification : G34, O16, O31

\title{
Sommaire
}

En utilisant un large échantillon de firmes nord-américaines, de 1999 à 2016, nous étudions l'effet des structures de gouvernance d'entreprise, en particulier la propriété, les caractéristiques des conseils d'administration et les contrats de rémunération des dirigeants sur l'intensité et l'efficacité de l'innovation. Nous considérons les dépenses de R\&D et les brevets comme mesures de l'innovation, et évaluons les conséquences des ralentissements économiques de 2000 et 2008. Les investissements en R\&D augmentent avec la propriété par les détenteurs de blocs institutionnels et avec le nombre de propriétaires institutionnels, confirmant le rôle clé que jouent les institutions dans les activités d'innovation des entreprises. La $R \& D$ est plus élevée pour les entreprises avec des conseils d'administration plus indépendants, plus de femmes parmi les membres du conseil et plus d'administrateurs externes. Les entreprises où une même personne occupe les postes de PDG et président du conseil ont une intensité de $R \& D$ plus faible, tout comme les entreprises davantage détenues par les administrateurs et dont l'âge moyen des membres du conseil d'administration est plus élevé. L'innovation est liée négativement aux niveaux de salaire des PDG, mais positivement liée au rapport des incitations à la rémunération totale. Toutefois, ces incitations réduisent le nombre de brevets. La récession de 2000 n'a pas eu d'effet systématique sur la $R \& D$, alors que la récession de 2008 a eu un effet positif sur la $R \& D$.

Mots clés : Gouvernance d'entreprise, Finance corporative, Innovation, R\&D, Canada, États-Unis.

Classification JEL : G34, O16, O31 


\section{Introduction}

Innovation is recognized as a key driver of economic development and growth, both at the firm and country levels. While there is a considerably large body of literature addressing a wide range of internal and external factors affecting innovation, we still do not have a clear picture of the effect of governance factors on innovation activities, the interactions of these factors, and how they differ across countries. A growing area of recent literature focuses on the impact of governance quality on innovation intensity in the larger context of agency theory. Whereas a substantial number of these papers look at the impact that each separate governance mechanism has on innovation levels of firms, like for example, ownership structure and board independence, this paper takes a novel approach by considering a large variety of governance structures simultaneously in the context of innovation intensity.

The various governance mechanisms relationship to investment and innovation activity of firms constitute a relevant body of literature in finance studies, and have remained core in the current debate, in particular from the agency and resource dependence theories. From an agency theory perspective, discussion has focused on the role of institutional ownership, boards of directors and CEO compensation structures on firms' R\&D investment levels (Deutsch, 2005, 2007; Brossard et al., 2013). One of the main arguments is that managers and shareholders have conflicting roles regarding innovation investment, and boards help mediate these conflicts (David et al., 2011; Hansen and Hill, 1991; Hirshleifer and Thakor, 1992). The resource dependence theory brings to light the importance of analyzing specific characteristics and dynamics between managers and the board of directors, as managers are not necessarily inherently averse to the risk brought by innovation investment decisions (Chen, 2014); however, their decisions on innovation can be influenced by their career stage (GonzálezUribe and $\mathrm{Xu}, 2014)$ and the risk levels of investments in innovation.

Although institutional ownership structure theory relates it directly to innovation activity (Aghion et al., 2013), empirical studies present conflicting results. A number of studies, mainly focusing on U.S. 
firms, have found evidence that the ownership stakes of institutions are positively related to innovation intensity (Bushee, 1998; Eng and Shackell, 2001; Cebula and Rossi, 2015); others find a negative link between innovation intensity and institutional ownership (Graves and Waddock, 1990; Minetti et al., 2015). Institutional ownership is defined as the stakes that large financial organizations, pension funds or endowments hold in companies. These institutions generally purchase large blocks of a company's outstanding shares and can exert considerable influence upon its management. ${ }^{1}$

The relationship of executive compensation contracts to a firm's innovation level has similar inconclusive results. For example, the theoretical model developed by Manso (2011) has the empirical implication that parts of CEO incentive compensation, like golden parachutes and managerial entrenchment, may be part of an optimal contract that motivates innovation activities. This conjecture is confirmed by González-Uribe and Xu (2014), who find that CEOs with long horizons, measured by the number of years remaining in their contract, have higher investments in R\&D and a higher R\&D quality, as captured by greater patent citations. Other studies find a negative relationship of R\&D spending and CEO compensation (Bizjak et al., 1993), and no relation of R\&D spending with the value of employee option grants (Matsunaga, 1995), while Cheng (2004) shows that changes in R\&D spending and changes in CEO option and total compensation are positively associated.

With respect to the impact of the boards on innovation activity, Balsmeier et al. (2017) investigate the link between board independence and the innovation process. While they find no impact on R\&D spending, they report that firms with independent boards have more patents and citations.

However, an unanswered question in this literature is how these elements — institutional ownership, board of directors and CEO compensation — interact and affect firms' innovation intensity and performance, especially across regional contexts and economic environments. Coffee (1999) for example

\footnotetext{
${ }^{1}$ Aghion et al. (2013, p. 280) define institutional ownership as those institutional characteristics in play for decision making, and in their analysis include the number of institutional owners, the number of shares issued, and the outstanding shares held by each institution.
} 
emphasizes that in times of financial crises there are higher levels of information asymmetry and uncertainty due to general market conditions. Therefore, we assume that the interaction between these elements is not static.

We take a novel approach and investigate simultaneously these well-known corporate governance structures and their impact on innovation intensity at the firm level. We contribute to the literature first by incorporating a series of ownership structure measures, a large number of board characteristics and aspects of executive compensation contracts in our analysis of innovation intensity. Second, we use a large sample of firms from both the U.S. and Canada, which allows us to capture any divergence in these relationships between the two countries. Third, our sample covers the years 1999 through 2016, and allows for an exploration of possible differential innovation intensities in expansionary vs. contractionary economic environments, as many innovation decisions can be affected by the economic and general business context, as for example, rapid technological change (Mazzucato and Tancioni, 2012; Mazzucato, 2013; Cremers et al., 2017), a financial crisis (Fralich and Papadopoulos, 2018), or increased competition (Liao and Lin, 2017).

We find that R\&D investment increases with ownership concentration in general, and blockholders stakes in particular and with the number of institutions, while the proportion held by the top five institutions has a negative impact on innovation. We observe higher R\&D expenditures for firms with more independent boards, more females serving on the board and for higher outside directorships held on average by all board members in a firm. Consistent with findings of prior studies, we report that firms with larger boards, and with a CEO who also serves as the chair of the board exhibit lower R\&D intensity, pointing to possibly higher agency costs. $R \& D$ is also lower for firms with higher collective ownership by board members and for higher average age of board members. Further, R\&D expenditures are negatively related to CEO salary levels, but positively to the ratio of incentives to total compensation. Taken together, these results confirm that incentive compensation leads to better alignment of interests 
between shareholders and management and, consequently, improved long-term decisions for the firm, such as higher investments in research, and potentially fostering long-term growth. Larger firms and firms with higher market to book value show higher levels of innovation. Surprisingly, more free cash flow reduces R\&D investment, although the effect is small. Finally, we do not find any changes in innovation investment during the 2000 recession; however, a significant increase is observed during the 2008 financial crisis.

The paper is structured as follows, after this introduction we provide a background discussion on the different aspects of governance factors and their impact on innovation. Section 3 presents the data and methodology. Section 4 presents the empirical results, and section 5 concludes.

\section{Theoretical framework and research hypotheses}

The latest Science, Technology and Industry Scoreboard (OECD, 2017) provides data on innovative efforts at the firm and country levels with a comparison across countries. One of the key insights of the report, centered around the business enterprise expenditure on R\&D (BERD), points that countries with BERD above the OECD median (like the U.S.) show an increase of R\&D expenditure for the period 2005-2015. In contrast, countries with below median BERD show a decrease of R\&D expenditure over the same period, such as the case for Canada. The understanding of these differences has been at the core of the agenda of innovation policy, as it has been widely argued that R\&D is highly correlated to innovation output and firm performance (Crépon et al., 1998). But what makes a firm engage in innovation activities, invest in innovation and boost innovation performance? These questions have sparked an international debate from several bodies of literature. As our sample includes U.S. and Canadian firms and spans a period covering two economic contractions, this study contributes to our better understanding of these issues. 
Evolutionary economics generated an important debate regarding the correlation between technological change and financial bubbles. Mazzucato and Tancioni (2012) show that, as innovation is a complex process frequently ending in failure, the market often penalizes firms that announce the undertaking of a challenging R\&D project, and this acts as a deterrent for decision-making on innovation investment. Overall, these studies shed light on the need to understand the effects of various firms' characteristics on innovation decisions, and emphasize that decisions are dependent on the financial and economic context. Our study contributes to bridge this gap by analyzing the role of different dimensions of corporate governance on innovation at the firm level, namely institutional ownership, boards of directors, and executive compensation, while accounting for firm characteristics.

Various innovation studies contribute to our understanding of innovation determinants at the firm level, and the relationship of innovation intensity to innovation output and firms' productivity (Crépon et al., 1998; Crespi and Zuniga, 2012; Griffith et al., 2006; Polder, 2009; Mohnen et al., 2006). The main conclusion in these studies is that external factors like industry dynamics, regional characteristics, knowledge-technology bases, government and public policies, culture and economic activity as well as internal characteristics, including global strategies, management, and culture influence firms' decision to engage in innovation activities. We complement these studies by looking at the role of corporate governance in shaping innovation investment decisions.

The effect of corporate governance on innovation has been studied at the national level (Jensen, 1986), and across economic sectors (Tylecote and Visintin, 2008). Mazzucato (2013) and Mazzucato and Tancioni (2012) argue that markets often penalize firms after the announcement of a new challenging R\&D project. Therefore, shareholder pressure can have a limiting effect on a firm's ability to invest in long-term innovation projects.

Agency theory posits that CEOs are inherently risk-averse (Jensen and Meckling, 1976), and they can influence the board in at least two ways: by affecting the membership of the board, and by controlling 
the information the board members look at to make decisions (Fralich and Papadopoulus, 2018). Deutsch (2005) conducts a meta-analysis that reveals a systematic relationship between board composition and some critical decisions, in agreement with the studies that call for the analysis of discrete decisions that involve a potential agency conflict (e.g., Hansen and Hill, 1991; Mallette and Fowler, 1992; Sundaramurthy, 1996). Lane et al. (1998) find that reducing non-systematic risk is necessary, as innovation outcomes are difficult to predict (Mazzucato, 2013).

The CEO has an important role in strategic change (see Haynes and Hillman, 2010, and Li and Tang, 2010) and R\&D investment (see Chen, 2014). Agency theory states that powerful CEOs may be reluctant to invest heavily in $\mathrm{R} \& \mathrm{D}$, whereas, resource dependence theory argues that directors (especially independent directors) advocate for high R\&D investment (Chen, 2014), and that firms' strategic orientation is linked to opportunities available to access the required resources (see for example Pfeffer and Salancik, 1978). Proponents of this theory argue that the board can aid in the formulation and implementation of firm strategy, including risky ones, such as innovation decisions.

Empirical evidence indicates a strong relationship between board composition and strategic decisions, as well as firm profitability. For example, Liao and Lin (2017) examine whether corporate governance and product market competition interact to affect the profitability of corporate $R \& D$ investments, and find that institutional ownership has positive effects on the ability of R\&D investment to create firm value.

We therefore argue that concurrently, these governance structures: ownership by institutions, board characteristics and elements of executive compensation drive firm's decision to invest in innovation.

\subsection{Institutional ownership}

Institutional owners are known for holding differential views on their support of risky and uncertain decisions (McConnel and Servaes, 1990; Brossard et al., 2013; Minetti et al., 2015). Some studies find 
that institutions are pressuring firms' managers by threatening to sell their stakes if the firm reports shortterm negative earnings and this is leading to reluctance to invest in risky endeavors such as R\&D (Hoskisson et al., 2002). While some studies find a negative relationship between institutional ownership and investments in R\&D (Graves, 1988; Bushee 1998), others find that institutions with diversified portfolios are pressuring directors and managers to undertake focused and opportunistic projects, and show a positive relationship between institutional ownership and innovation (David and Kochhar, 1996). Hoskisson et al. (2002), Minetti et al. (2015), and Qiu (2017) find relevant differences between ownership constituents, internal governance characteristics, and corporate innovation strategies, and the interaction of these elements affects the strategic decisions on innovation investment.

Although there is empirical evidence of a positive association between innovation and ownership stakes of institutions, overall, the results are somewhat mixed. For example, Aghion et al. (2013) identify a positive relationship between innovation and institutional ownership, and conclude that ownership by institutions has a small positive impact on $R \& D$, and a large positive effect on the productivity of $R \& D$ (measured by patents). Their theoretical model suggests that this positive effect is due to career concerns: managers dislike innovation risk, and better monitoring increases innovation incentives by insulating managers from the negative reputational effects of bad outcomes. To the extent that R\&D investments are subject to high levels of information asymmetry between managers and investors, R\&D activities may give rise to agency concerns (Liao and Lin, 2017). However, the presence of institutional owners may improve corporate control, corporate governance and, ultimately, innovation both quantitatively (Bohdan and Mukherjee, 2017; Francis and Smith, 1995) and qualitatively (Yang, 2016; Bohdan and Mukherjee, 2017).

We measure institutional ownership using four components: ownership concentration (total number of common shares held by institutions divided by the total number of shares outstanding), the number of institutions (total number of institutions that own shares in the firm), the percentage held 
overall by institutional blockholders of $5 \%$ or more, and the percentage owned by the top 5 institutions. We therefore state our first hypothesis as follows:

\section{Hypothesis 1: Institutional ownership positively influences $R \& D$ intensity.}

\subsection{Board Characteristics}

David et al. (2001) argue that managers and shareholders have conflicting views regarding innovation investment: while shareholders usually favor innovation investment, managers, being risk averse, prefer to reduce R\&D investment (Holmström, 1999; Hart, 1983; Hansen and Hill, 1991; Hirshleifer and Thakor, 1992; Bertrand and Mullainathan, 2003). Board structure and composition is an endogenous choice (Cremers et al., 2017; Adams et al., 2010), and the direction of causality between governance characteristics and performance is not completely clear, as suggested by Cremers et al. (2017). From the resource dependence theory Dalziel et al. (2011) suggest that the board's human and social capital shape how directors govern and offer advice to the firm and affect the ideas and resources that they provide.

Regarding boards of directors and their effect on innovation investment decisions, there are few elements that have been considered by the literature: board composition, board characteristics, and CEO power.

Studies have contributed to the understanding of the effect of the proportion of outside directors on firms' strategic decisions, but they reach conflicting results. On the one hand, Deutsch (2005) indicates a negative systematic relationship between the proportion of outside directors and firms' R\&D expenditure. He argues that there might be potential conflict of goals between shareholders and outside directors rooted in different attitudes toward risk, and need the presence of more "vigilant board members" (Kosnik, 1990). Similarly, Hill and Snell (1988) find that higher spending on innovation is associated with greater management stock holdings, and with lower outsider representation on the board; 
the latter result is at odds with the prediction of agency theory. Baran et al. (2018) find that in firms characterized by disproportionate inside control, the firms' top executives are more likely to file their own patents, suggesting a strong relation between insider control and innovation outputs. In fact Baysinger and Hoskisson (1989) argue that boards dominated by outside directors may lead firms to reduce investment in internal innovation and focus more on product diversification and external innovation. On the other hand, Deutsch (2007) argues that the proportion of outside directors is related to higher R\&D. Balsmeier et al. (2017) argue that as managers cannot easily evade the new board regulations in the U.S., they will have to appoint outside directors who are effective monitors, leading to improved firm performance when boards become more independent.

Jensen (1986, 1993) posits that outsiders' effectiveness is limited, as they have inferior knowledge about the business compared to that of insiders. Duchin et al. (2010) look at board effectiveness, its composition and the cost of acquiring information and show that board effectiveness is dependent on information cost. Specifically, when the cost of acquiring information is low (high), performance increases (worsens) when outsiders are added to the board. As innovation projects have limited information (Mazzucato, 2013) results are difficult to predict, and, in this context, the composition of board independence matters (Romano, 2005).

Dalziel et al. (2011) find a positive relationship between R\&D and Ivy League educational experience of inside and outside directors, the technical experience of outside directors, and outside directors' interlocks to low-technology firms. Chen (2014), Haynes and Hillman (2010), and Kroll et al. (2007) find a negative relationship between R\&D and entrepreneurial finance experience of outside directors, and advanced education of outside directors.

Empirical evidence suggests that the composition and characteristics of the board of directors is highly relevant for innovation decisions; however, CEO experience and power offer a mediating effect. Chen (2014) studies the impact of board capital and CEO power on innovation, using data on firms from 
the Taiwanese electronics industry. He finds that directors' education, their industry experience and interlocking directorate ties have a positive effect on innovation, and that powerful CEOs reinforce these effects. His empirical evidence also suggests that when powerful CEOs are present, directors with higher human and social capital will devote more effort to providing valuable strategic advice and resources, and thus will support R\&D investment to enhance innovative capabilities. Fralich and Papadopoulos (2018) report that stronger CEOs are better at reducing information asymmetry by accounting for information generated by their external networks.

As indicated by the literature, the composition and characteristics of the board can promote or deter the decisions to invest in innovation, but their effects are mediated by information asymmetries and CEO power. We therefore test :

Hypothesis 2: The set of skills and experience present in the board of directors positively influences strategic decisions associated with innovation.

\subsection{CEO compensation}

Aghion el al. (2013) view executive compensation as a driver for innovation investment. They suggest that results are consistent with two widely used models. The first one, emphasized by Hart (1983) and Bertrand and Mullainathan (2003), argues that managers prefer a quiet life and institutional investors force them to innovate (the lazy manager hypothesis). The second is based on a career concern model (Holmström, 1982). This argument is supported by findings of González-Uribe and Xu (2014), that CEOs with more years remaining in their contract are seen to pursue more influential, broad and varied innovations. This suggests that incentives to innovate decrease as CEOs' contracts reach expiration and innovation follows a cyclical pattern that overlaps those contracts. 
Due to the risky and uncertain nature of $R \& D$ investments, CEOs might favour short term and less risky investments. There is also the perception that markets may temporarily undervalue their firms based on current earnings (Chen, 2004), and perceive R\&D spending to have a negative effect on shortterm stock prices. According to Skinner and Sloan (2002) and Sloan (1993), a temporary undervaluation can negatively affect CEO compensation and threaten their job security. CEOs with this belief tend to sacrifice $R \& D$ to inflate current earnings.

Cheng (2004) contributes to this discussion, as his study focuses on the analysis of how changes in CEO compensation affect R\&D spending in two cases: first when the CEO approaches retirement, and second when the firm faces a small earnings decline or a small loss. This second hypothesis (the myopia problem: Baber et al., 1991; González-Uribe and Xu, 2014) is relevant to our study, as firms might face earnings decline in times of financial crisis. Cheng's (2004) study shows that compensation committees respond to potential opportunistic reductions in $R \& D$ spending and do so by adjusting the relation between changes in R\&D spending and changes in the value of CEO annual option grants.

In the context of executive compensation, the compensation type plays a key role. Manso (2011) argues that the optimal mix that motivates innovation is a combination of stock options with long vesting periods, option repricing, golden parachutes, and managerial entrenchment. He finds that motivating exploration involves tolerance (or even reward) for early failure and reward for long-term success, so not only overall performance, but also the path of performance matters for compensation.

As compensation has a relevant effect on $R \& D$ intensity, but also the optimal compensation mix matters, we therefore test :

Hypothesis 3: An optimal mix of compensation that includes short-term and longer-term compensation positively influences investment in innovation projects. 


\section{Data and Methodology}

\subsection{Data}

The starting point for the sample is all firms listed on the S\&P Composite 1500 Index and on the S\&P/TSX Composite Index. The S\&P Composite 1500 contains three leading indices, the S\&P 500 Large-Cap, the S\&P 400 Mid-Cap, and the S\&P 600 Small-Cap, and covers approximately 90\% of U.S. market capitalization. The S\&P/TSX Composite Index represents about $70 \%$ of the total market capitalization on the Toronto Stock Exchange (TSX) and includes 250 of the approximately 1500 companies on the exchange. As we are interested in differential firm innovation behavior and activities during periods of expansion and contraction, we start our sample in 1999 and end it in 2016, inclusive, which allows us to cover two periods of economic downturn: 2000 and 2008. We merge this initial dataset comprising 34,694 firm-year observations with firm characteristics, financial and market data from the Compustat database, ownership data from the Thomson Reuters Stock Ownership database and compensation data from Execucomp.

In addition, we create three new variables for each firm-year: totals for the top five executives' salary, bonus and total compensation. For the Canadian sample Execucomp coverage is very limited and we fill in the missing compensation variables by manually collecting data from annual proxy statements, available on SEDAR. We use ISS (formerly RiskMetrics) Directors data, available on Wharton Research Data Services (WRDS) to calculate and merge, for each firm-year, totals for: number of directors, independent directors, female board directors, number of shares held collectively by board members, average age of board members, average number of outside directorships and an indicator for incidence of a dual role for CEO and chair of the board. We then merge all these variables to our original dataset by using CUSIPs and year. In line with other empirical studies, we drop all financial firms from the sample, as their governance structure is systematically different and might distort the results if included. 
After dropping all observations with missing variables, the result is an un-balanced panel dataset of 23,659 firm-year observations.

\subsection{Model Specification}

We begin our analysis with an OLS regression examining the determinants of our main measure of innovation level for a firm, with $R \& D$ as the dependent variable. We focus first on firm level determinants of innovation, with special emphasis on governance, ownership and executive compensation. Our most general model is as follows:

$\operatorname{Ln}(R \& D \text { expenditures })_{i, t-1}=\alpha+\beta_{1}($ Variable of Interest: Ownership/Board/CEO Compensation $)+$ $\beta_{2}$ U.S. $+\beta_{3} 2000$ Recess. $+\beta_{4} 2008$ Recess. $+\beta_{5}$ Size $_{1, t}+\beta_{6}$ Leverage $_{i, t}+\beta_{7}$ CapEx $_{i, t}+\beta_{8}$ FCF $_{i, t}+$ $\beta_{9} M B_{i, t}+\beta_{10} R O A_{i, t}+\beta_{11} H H I_{i, t}+\delta_{i}+\lambda_{t}+\varepsilon_{i, t}+e$

where $i$ indexes firms and $t$ indexes time, $\delta$ captures exchange listing fixed effects, $\lambda$ industry fixed effects and $\mathcal{E}$ year fixed effects, in order to account for inter industry, year and exchange heterogeneity. In order to partially address the endogeneity issues known to be present in analyses relating innovation and firmspecific characteristics, we lag the innovation variables by one year. ${ }^{2}$ All our models include fixed effects for the exchange the firm is listed on as well as industry and year fixed effects, controlling thus for the variation introduced in the models by these variables. In alternate models we introduce, one at a time the groups of variables of interest: ownership, board characteristics and CEO compensation, respectively. In a final model we include all of them simultaneously. Following prior literature, we include a series of control variables known to impact the levels of R\&D expense of a firm: Size, which is the natural

\footnotetext{
${ }^{2}$ In unreported analyses, we replicate the models of Table 3 using 2- and 3-year lags for all our dependent variables, with very similar results.
} 
logarithm of total assets; capital expenditures divided by total assets (Capex/TA); firm risk (Leverage) which is the ratio of total liabilities to total assets; free cash flow $(F C F)$ calculated as earnings before interest and taxes (EBIT) less taxes, plus depreciation, less capital expenditures and less change in working capital; market-to-book ratio $(M / B)$; return on assets $(R O A)$-the ratio of net income to total assets; and the Herfindahl-Hirschman Index $(H H I)$ to capture the market concentration of an industry.

Ownership Variables: We include four measures of ownership. First is ownership concentration (Own. Concen.), defined as the total number of common shares held by institutions divided by the total number of shares outstanding. The second ownership variable is the number of institutions (No. Inst.), which is the total number of institutions that own shares in the firm. The third variable is the percentage held overall by institutional blockholders of $5 \%$ or more (Block Inst.), and the last one is the percentage owned by the top 5 institutions (Own Top5).

Board Composition Variables: We include as controls of the ownership characteristics: Board Size, percent of independent directors on the board (Indep. Dir.), CEO-Chair duality (CEO Duality), percentage of females on the board (Board Females), total ownership by the board (Board Own.) and average director age (Dir. Age).

CEO compensation Variables: Compensation variables include CEO Salary and CEO incentive compensation as a fraction of total compensation (CEO Inc. Comp.). 


\section{Empirical Results}

\subsection{Descriptive Summary and Univariate Tests}

To evaluate the effect of corporate governance on innovation we employ two dependent variables as proxies for innovation. First, we use R\&D expenditures as a proxy for innovation intensity. For example, Crépon et al. (1998) use R\&D investment, and Chan et al. (2001) use the ratios of R\&D to sales and to market value of equity. Second, we use the total number of patents filed as a proxy for innovation output. Aghion et al. (2013) and Fang et al. (2014) use total number of patents per firm, while Hirshleifer et al. (2013), investigating innovation efficiency, focus on the number of patents and citations over R\&D expenditures.

As one of our main questions of interest is the differential level of innovation intensity during expansionary and contractionary economic environments, our key variables are year indicators for the two major economic downturns during our sample data: 2000 and $2008 .^{3}$ In addition, given the nature of our data we include an indicator variable for U.S. firms in order to capture any systematic differences between $R \& D$ expenditures in the two countries.

In order to test the effect of corporate governance on innovation we include three sets of variables: ownership, board characteristics, and executive compensation, together with firm-specific controls. Table 1 presents the main variables. Table 2 presents the descriptive statistics for the main variables used in the study, grouped into four categories: firm characteristics, ownership, board characteristics, and compensation. From Panel A of Table 2 we see that the average firm in our sample spends about $\$ 109$ million annually on R\&D and generates about 13 patents a year. Average total assets are $\$ 17,580$ million and ROA is approximately 7\%. Panel B shows that the average firm has 188 institutional owners, and mean holdings by institutional blockholders is $13 \%$. The average board size is nine members, $75 \%$ of

\footnotetext{
${ }^{3}$ In unreported analyses we replace the 2000 and 2008 year indicators with longer periods for the recession and results are comparable.
} 
whom are independent and $12 \%$ are females; the average board member is 61 years old, and boards hold on average a total of approximately $8 \%$ of the firm. With respect to compensation variables, we note that the average CEO salary is $\$ 626,000$ and incentives represent $55 \%$ of total compensation.

[Table 1]

[Table 2]

Table 3 contains differences in means for the samples of Canadian and U.S. firms for all our sets of variables. Canadian firms have higher levels of leverage and lower levels of R\&D and patents (Panel A). Ownership is more concentrated in Canada, Canadian firms have lower numbers of institutional owners and lower institutional blockholdings (Panel B). Both salaries and percentages of incentives to total compensation of Canadian CEOs are significantly smaller, as shown in Panel $\mathrm{C}$ of Table 3 . We further analyse the differences in corporate governance in a multivariate setting in the next section.

[Table 3]

In Table 4 we present results of the Variance Inflation Factor (VIF) and tolerance (1/VIF) tests for multicollinearity for the main variables, and show that none of our variables are redundant. Table 5 shows the correlation matrix of the main variables.

[Table 4]

[Table 5]

\section{2. $R \& D$ Expense Model}

Results of different variations of the OLS regression modelling the natural logarithm of the R\&D expense as a function of our main variables and controls are presented in Table 6.

[Table 6]

Model 1 is the most basic model using the specification in equation (1) above. In the other four models of Table 6 we add to the general model a series of variables related to ownership structure, board 
characteristics and executive compensation, respectively. Model 2 includes all our ownership structure variables: ownership concentration, percentage held by institutional owners, natural logarithm of the total number of institutions, blockholders' ownership percentage, and percentage held by the top 5 institutions, in addition to the firm-specific variables presented in Model 1. Model 3 adds to the specification of Model 1 various characteristics of the board of directors: board size, board independence (measured as the number of independent directors scaled by the total number of directors on the board), indicator for CEO-chair of the board duality, percentage of females on the board, total ownership by directors as a fraction of total shares outstanding, average age of directors and total number of outside directorships. In Model 4 we add to the base model two variables measuring executive compensation: natural log of CEO salary and CEO incentive compensation, defined as total compensation minus salary divided by total compensation. In unreported analyses, we replaced compensation variables based on CEO's contract with the same variables capturing totals of the top 5 executives, and results are qualitatively and quantitatively similar. Finally, Model 5 includes all our variables simultaneously.

Looking at the overall results in Table 6 and focusing on our indicators capturing years of economic downturn, we note that firms in our sample do not exhibit any systematic differences in R\&D expenditures compared to the other years. The only exception is for the 2008 financial crisis where three of the models (1,3 and 4) show positive and significant coefficients, indicating larger R\&D expenses overall in 2008, at the beginning of that economic slowdown. We interpret that as a confirmation that R\&D decisions are made by each firm internally, as part of a long-term strategy, and are not strongly influenced by the short-term variations in cash flows or the overall state of the economy. Once a firm starts a multi-year R\&D project, it is not easy to cut funding when a recession arrives.

The ownership variables, present in Models 2 and 5, show that the ownership structure of a firm has a strong relationship with the investments a firm makes. We find that $R \& D$ investment is increasing with ownership concentration in general, with a larger number of institutions present and with a larger 
proportion of institutional block ownership, while a larger ownership by the top 5 institutional owners has a negative impact on our innovation measure. These results are in line with findings of Aghion et al. (2013), showing that institutional ownership is positively related to innovation. In terms of economic significance, focusing on Model 5, we note that a $1 \%$ increase in block institutional ownership boosts R\&D expense by about 0.87 ; for the average level of $R \& D$ in our sample of $\$ 168$ million, that represents an increase of about $\$ 66$ million. ${ }^{4}$ These results are consistent with Hypothesis 1.

The next set of variables we focus on are board of directors' variables, which are known in the literature to have an impact on the governance quality of a firm. Based on the results of models 3 and 5 we document higher R\&D expenditures for firms with more independent boards, more females serving on the board and for higher outside directorships held on average by all board members in a firm. Consistent with findings of prior studies (see Deutsch, 2005), we report that firms with a CEO who also serves as the chair of the board and with higher ownership by directors as a group, exhibit lower R\&D intensity, pointing to possibly higher agency costs in these firms. R\&D is also lower for firms with higher collective age of board members. Our result is relevant to the discussion from González-Uribe and Xu (2014), who emphasize the argument that decisions on innovation investment can be influenced by career stage. Economically, a $10 \%$ increase in board independence (corresponding to the addition of an independent board member to the average board in our sample) leads to a significant increase of about $\$ 5$ million in R\&D, and if the new board member is a female, that increase corresponds to about $\$ 8$ million. The significance of this group of variables supports Hypothesis 2 .

Finally, the last group of covariates are executive compensation variables. These results are shown in Model 4 of Table 6, where we see that R\&D expense is negatively associated to CEO salary levels (although not significant at standard significance levels) but positively to the ratio of incentive to

\footnotetext{
${ }^{4} 100\left(\mathrm{e}^{0.87}-1\right)=138 \%$; for the average level of R\&D of $\$ 168 \mathrm{M}$ this is an increase of about $\$ 66 \mathrm{M}$.
} 
total compensation. For example, a $10 \%$ increase in the ratio of incentive to total compensation is associated with an economically significant increase of about $\$ 17$ million in R\&D. These results confirm that incentive compensation leads to more alignment of interests between shareholders and management and, therefore, better long-term decisions for the firm, such as higher investments in research. Manso (2011) and González-Uribe and Xu (2014) obtained similar results. These results are in line with our expectations (Hypothesis 3).

All our models, as mentioned before, include our set of firm-specific controls. As table 6 shows, results are robust to the different specifications, as all coefficients maintain their sign and significance and thus, we discuss the results in general, for all our models. As documented in prior literature (Crespi and Zuniga, 2012), our measure of firm size, proxied by the natural logarithm of total assets has a positive association to the R\&D expense levels, suggesting that larger firms tend to invest more in innovation. ${ }^{5}$ Similarly, firms with higher market-to-book ratios, and thus with higher market valuations, exhibit higher investments in R\&D. Innovation intensity is significantly decreasing with firm leverage, ratio of capital expenditures to total assets, free cash flow, $R O A$ and industry competition level. In other words, firms with higher debt levels, higher capital investments tend to invest less in R\&D. The governance literature has extensively documented that firms with higher levels of free cash flows - more cash than profitable investment opportunities - are subject to higher agency costs, and we find that these firms also invest less in R\&D. Interestingly, a firm in a competitive industry has lower innovation levels, all else equal, in our sample. Economically, a $1 \%$ increase in $R O A$ decreases R\&D by 0.551 , or approximately $\$ 92$ million when starting at the average values of the $R O A$ in our sample of $\$ 168$ million. $^{6}$

Regarding leverage, Serrasqueiro et al. (2011) find that, for Portuguese SMEs, short-term debt has a positive influence on $R \& D$ intensity, while long-term debt has a positive influence only when it is

\footnotetext{
${ }^{5}$ In unreported tests, we replace natural log of total assets with natural log of Market Value as proxy for size, with qualitatively and quantitatively similar results.

${ }^{6}$ Using the coefficient of -0.596 for $R O A$ in column 5 of Table 6 , we calculate the multiplier as: $\mathrm{e}^{-0.596}=0.551$.
} 
sufficiently high. They also find that cash flow has a positive effect on innovation. These results differ from ours', since we find that leverage has an overall negative effect on R\&D, and cash flow has a small negative effect. One possible explanation for this divergence is that Serrasqueiro et al. (2011) focus on SMEs, which are more financially constrained than firms in our sample, which are a mix of medium and large enterprises.

In Tables 7 and 8 we repeat the analyses by separating the sample into Canadian and U.S. firms respectively, and report results for all models similar to the ones in Table 6 . We include industry and year fixed effects, as before, but drop the stock exchange fixed effects, as for Canadian firms there is only one dominant exchange, TSX with very little variation. For brevity we discuss only the observed differences between the two sub-samples. Starting with our ownership variables, we find no differences between the two countries, with both showing the same positive relation of $\mathrm{R} \& \mathrm{D}$ expenditures to ownership concentration, number of institutional owners and percentage held by blockholder institutions. A higher concentration in the hands of the top 5 institutions is linked to lower $\mathrm{R} \& \mathrm{D}$, similar to the findings in the overall sample.

[Table 7]

[Table 8]

We find a lot more variation in these relationships for the board variables. As can be seen in Table 8, the U.S. sub-sample results are very similar to the overall sample (Table 6), both in sign and significance levels. The only exception is board size, which is negatively related to innovation intensity for U.S. firms, while not significant in the entire sample. Canadian firms' board structures do not show much significance in their relationship to innovation (see Table 7). We note an interesting result in the impact of board ownership: for U.S. firms (and full sample), an increase in the percentage owned by the board, collectively, is associated with smaller R\&D expense, all else equal, while Canadian firms exhibit the opposite relationship: higher board ownership is associated with higher R\&D expenses. As levels of 
board ownership are slightly higher for U.S. firms than for Canadian ones, it seems that the $7.6 \%$ average in Canada is serving as an alignment mechanism for interests of board members with the interests of shareholders'; while, for U.S. firms (average of 9.2\%), the additional ownership tilts this relationship to more of an entrenchment mechanism. Results of firms' characteristic variables impact on innovation are found to be very similar between the two countries. Finally, Canadian firms show no differential impact on innovation investment during both recessionary periods covered by our sample, while U.S. firms show an increase in R\&D during the 2008 financial crisis in three of our five models.

In Table 9, we run the same model as in Table 6 - with the log of R\&D as dependent variable but include random effects. We present the results for completeness, however we do not discuss the results in detail. We performed the Hausman test on whether the fixed effects (FE) or random effects (RE) model is more appropriate for a panel data regression and results show the fixed effects model is recommended.

\subsection{Number of Patents Model}

We focus next on the second dependent variable used to capture innovation output at firm level: number of patents filed. Patents capture a different, later stage of innovation activity for a firm, and thus can be seen as a measure of efficiency of innovation (Hirshleifer et al., 2013). The number of patents comes from Professor Hall's website. ${ }^{7}$ We model the number of patents with an OLS regression with natural $\log$ of number of patents as the dependent variable. We focus first on firm level determinants of innovation, with special emphasis on ownership, board governance and executive compensation, as before. Our most general model is as follows:

\footnotetext{
${ }^{7}$ https://eml.berkeley.edu/ bhhall/.
} 


$$
\begin{aligned}
& \text { Ln(No. of Patents })_{i, t-1}=\alpha+\beta_{1} \text { U.S. }+\beta_{2} 2000 \text { Recess. }+\beta_{3} 2008 \text { Recess. }+\beta_{4} \text { Size }_{1, t}+ \\
& \beta_{5} \text { Leverage }_{i, t}+\beta_{6} \text { CapEx }_{i, t}+\beta_{7} F C F_{i, t}+\beta_{8} M B_{i, t}+\beta_{9} \text { ROA }_{i, t}+\beta_{10} H H I_{i, t}+\delta_{i}+\lambda_{t}+e
\end{aligned}
$$

where $i$ indexes firms and $t$ indexes time, $\delta$ captures industry fixed effects and $\lambda$ year fixed effects. The detailed description of our variables is presented in Table 1. As in our prior model, we lag the innovation variables by one year. All our models include industry and year fixed effects, controlling thus for the variation introduced in the models by these variables. Table 10 shows results of different variations of this OLS regression.

\section{[Table 10]}

Results are, in general, very similar to the ones in Table 6 - with R\&D expenditures as dependent variable. Noteworthy, U.S. firms have significantly more patents than Canadian ones, as shown by the positive and significant (in 4 of 5 models) coefficient of the U.S. indicator. Moreover, there were systematically less patents filed during the 2008 financial crisis than in any other year of the sample, as expected. The relationship of ownership variables and board and firm characteristics with the number of patents filed by firms is found to be identical to their relationships with $R \& D$ expense, in both direction and magnitude. With respect to compensation, CEO salary levels are not related to the number of patents a firm files, however, and contrary to our results in Table 6, a higher ratio of incentives to total compensation is related to a lower number of patents filed.

\subsubsection{Endogeneity Issues}

Studies attempting to show causality between various governance structures and firm-specific characteristics, such as the amount of $R \& D$ investment in a given year suffer from serious endogeneity concerns. The sources of endogeneity are one of three issues with the variables involved: model misspecification (or omitted variables), measurement errors and simultaneity. It is conceivable that any 
of these could lead to biased OLS coefficients due to correlation between explanatory variables and the error term. For example, it is possible that other variables (omitted, or unobservable) can determine both the levels of R\&D investments and firms' various governance mechanisms in place. Alternatively, it is difficult to determine the direction of causality between these variables. As mentioned above, we use a lag of one year for the R\&D expense variable in our models, and this partially addresses the reverse causality issues. As a robustness check, we replicate our analyses with 2- and 3-year lags of the innovation variable relative to other controls and results remain qualitatively similar, indicating that there is a possible impact of quality of governance structure on innovation intensity.

\section{Discussion and conclusions}

We analyze the impact of firms' governance structures on the intensity and efficiency of innovation by employing a large sample of U.S. and Canadian firms from 1999 to 2016, while distinguishing between different economic cycles. In the design of our tests, we control for general firm characteristics shown in the literature to impact innovation, together with stock exchange, industry and year fixed effects. At the same time, we employ different governance measures related to the ownership structure, internal governance measures focusing on board of directors' attributes, as well as executive compensation structures, all aimed at investigating the possible mitigating roles these have on a firm's innovation intensity.

We find that R\&D investment increases with ownership concentration in general, and blockholders in particular and with a larger number of institutions, while larger institutional ownership and the proportion held by the top five institutions have a negative impact on innovation. We observe higher R\&D expenditures for firms with more independent boards, more females serving on the board and for higher outside directorships held on average by all board members in a firm. Consistent with findings of prior studies, we report that firms with larger boards, and with a CEO who also serves as the 
chair of the board exhibit lower R\&D intensity, pointing to possibly higher agency costs. R\&D is also lower for firms with higher collective ownership by board members and for older age of a board, on average, also consistent with prior studies (see for example González-Uribe and $\mathrm{Xu}, 2014$ ).

R\&D expense is negatively related to CEO salary levels, but positively to the ratio of incentive to total compensation. These results confirm that incentive compensation leads to more alignment of interests between shareholders and management and, consequently, better long-term decisions for the firm, such as higher investments in research. However, with respect to patents, CEO salary levels do not affect the number of patents a firm files, and a higher ratio of incentives to total compensation is related to a lower number of patents filed.

These findings have relevant implications for practitioners and policymakers regarding fostering innovation intensity and efficiency, as they suggest that smaller and more diverse boards have a positive impact on innovation intensity. Innovation intensity has been recognized as an important engine of firm productivity (Crépon et al., 1998), and specific modes of corporate governance can foster innovation intensity (investment in R\&D), and have effects on innovation output (patents filed). Board characteristics do play a significant role in innovation intensity and output, and more diverse boards can incentivise engagement in innovation activities with good results in terms of outputs measured as patents. However, in terms of compensation, the implications call for the need to implement a good balance between short-term and long-term compensation, that contributes to boost innovation intensity, but also innovation output. Another finding that calls for policy attention refers to innovation intensity significantly decreasing with firm leverage, and with the ratio of capital expenditures to total assets. Therefore, firms with higher debt levels might be engaging in a vicious circle by reducing their innovation intensity levels. Surprisingly, higher levels of free cash flow, ROA and industry competition levels, all reduce $R \& D$ investment. These findings deserve additional attention. 
One of our initial assumptions was that economic downturns would have an impact on innovation, as firms either make a decision to not engage in risky projects, or make a strategic decision to increase innovation investment with the expectation to have a repay at the end of the financial downturn. Our results suggest little effect of economic downturns on innovation, in particular for innovation output (number of patents filed).

Finally, this paper has some limitations. First, we only compare Canada and the U.S. due to the availability of data on all the variables used for this study. In addition, the number of observations is significantly higher for the U.S. than for Canada. A second limitation is the type of dependent variables used in this study. We used investment in $R \& D$ as a proxy for innovation intensity, and patents as a proxy for innovation output. These two variables have been widely used by other authors but might not capture all firm investment in innovation activities, or all innovation outputs.

\section{Acknowledgments}

A previous version of this paper was presented in 2019 at the internal Management Speaker Series at the Sobey School of Business. We thank all the attendees to this Speaker Series for their comments.

\section{References}

Adams, R.B., Hermalin, B.E., and Weisbach, M.S. 2010. The role of boards of directors in corporate governance: A conceptual framework and survey. Journal of Economic Literature . 48(1):58-107.

Aghion, P., Van Reenen, J. and Zingales, L. 2013. Innovation and institutional ownership. American Economic Review. 103(1):277-304.

Baber, W.R., Fairfield, P. and Haggard, J. 1991. The effect of concern about reported income on discretionary spending decisions: The case of research and development. Accounting Review. 66(4):818-829.

Balsmeier, B., Fleming L., Manso, G. 2017. Independent boards and innovation. Journal of Financial Economics. 123(3):536-557.

Baran, L., Forst, A. and Via, M. 2018. Dual Class Share Structure and Innovation.

Baysinger, B.D., and Hoskisson, R.E. 1989. Diversification strategy and R\&D intensity in large multiproduct firms. Academy of Management Journal, 32: 310-332.

Bertrand, M., and Mullainathan, S. 2003. Enjoying the Quiet Life? Corporate Governance and Managerial Preferences. Journal of Political Economy. 111(5):1043-75. 
Bikhchandani, S., Hirshleifer, D., and Welch, I. 1992. A theory of fads, fashion, custom, and cultural change as informational cascades. Journal of Political Economy. 100(5):992-1026.

Bizjak, J., J. Brickley, and J. Coles. 1993. Stock-based incentive compensation and investment behavior. Journal of Accounting and Economics. 16: 349-372.

Bohdan, R., and Mukherjee, T. 2017. Dual Ownership Activism and Innovations of U.S. Multinationals. Brossard, O., Lavigne, S. and Sakinç, M.E. 2013. Ownership structures and R\&D in Europe: the good institutional investors, the bad and ugly impatient shareholders. Industrial and Corporate Change. 22(4):1031-1068.

Bushee, B.J. 1998. The Influence of Institutional Investors on Myopic R\&D Investment Behavior. The Accounting Review. 73(3):305-333.

Cebula, R.J., and Rossi, F. 2015. Ownership structure and R\&D: an empirical analysis of Italian listed companies. PSL Quarterly Review. 68(275):297-325.

Chan, L., Lakonishok, J. and Sougiannis, T. 2001. The stock market valuation of research and development expenditures. The Journal of Finance. 56(6):2431-2456.

Chen, H.-L. 2014. Board Capital, CEO power and R\&D Investment in Electronics Firms. Corporate Governance: An International Review. 22(5):422-436.

Cheng, S. (2004) R\&D Expenditures and CEO Compensation. 2004. The Accounting Review. 79(2):305328.

Coffee, J. 1999. The future as history: the prospects for global convergence in corporate governance and its implications. Northwestern University Law Review. 93:641-707.

Cremers, K.J.M., Litov, L.P., and Sepe, S.M. 2017. Staggered boards and long-term firm value, revisited. Journal of Financial Economics. 126:422-444.

Crépon, B., E. Duguet, and J. Mairesse. 1998. Research, innovation, and productivity: An econometric analysis at the firm level. Economics of Innovation and New Technology. 7(2):115-158.

Crespi, G., and P. Zuniga. 2012. Innovation and Productivity: Evidence from Six Latin American Countries. World Development. 40(2):273-290.

Dalziel, T., Gentry, R.J., and Bowerman, M. 2011. An Integrated Agency-Resource Dependence View of the Influence of Directors' Human and Relational Capital on Firms' R\&D Spending. Journal of Management Studies, 48(6):1217-1242.

David, P., and Kochhar, R. 1996. Barriers to effective corporate governance by institutional investors: Implications for theory and practice. European Management Journal. 14(5):457-466.

David, P., Hitt, M.H., and Gimeno, J. 2001. The influence of activism by institutional investors on R\&D. Academy of Management Journal. 44:144-158.

Deutsch, D. 2005. The impact of board composition on firms' critical decisions: A meta-analytic review. Journal of Management. 31(3):424-444.

Deutsch, D. 2007. The Influence of Outside Directors' Stock-Option Compensation on Firms' R\&D. Corporate Governance. 15(5):816-827.

Duchin, R., Matsusaka, J.G. and Ozbas, O. 2010. When are outside directors effective? Journal of Financial Economics. 96(2):195-214.

Duncan, R.B. 1972. Characteristics of organizational environments and perceived environmental uncertainty. Administrative Science Quarterly. 17(3):313-327.

Eng, L.L. and Shackell, M. 2001. The Implications of Long-Term Performance Plans and Institutional Ownership for Firms' Research and Development (R\&D) Investments. Journal of Accounting, Auditing \& Finance. 16(2):117-139.

Fang, V. W., Tian, X. and Tice, S. 2014. Does Stock Liquidity Enhance or Impede Firm Innovation? The Journal of Finance. 69(5): 2085-2125.

Finkelstein, S., Boyd, B. 1998. How much does the CEO matter? The role of managerial discretion in 
the setting of CEO compensation. Academy of Management Journal. 41:179-199.

Fralich, R. and Papadopoulos, A. 2018. The financial crisis, acquisition premiums and the moderating effect of CEO power. Long Range Planning. 51(2):204-218.

Francis, J. and A. Smith. 1995. Agency costs and innovation some empirical evidence. Journal of Accounting and Economics. 19(2):383-409.

González-Uribe, J. and Xu, M. (2014) Corporate innovation cycles and CEO contracts. Working paper. London School of Economics.

Graves, S.B. 1988. Institutional ownership and corporate R\&D in the computer industry. Academy of Management Journal. 31:417-428.

Graves S.B., and Waddock S.A. 1990. Institutional ownership and control: Implications for long-term corporate strategy. Academy of Management Executive. 4(1):75-83

Griffith, R., E. Huergo, J. Mairesse, and B. Peters. 2006. Innovation and Productivity across Four European Countries. Oxford Review of Economic Policy. 22(4):483-498.

Hansen, G.S., and Hill, C.W.L. 1991. Are institutional investors myopic? A time-series study of four technology driven industries. Strategic Management Journal. 12(1):1-16

Hart, O.D. 1983. The Market Mechanism as an Incentive Scheme. Bell Journal of Economics. 14(2):36682.

Haynes, K., and Hillman, A. 2010. The effect of board capital and CEO power on strategic change. Strategic Management Journal. 31(11):1145-1163.

Hill, C.W.L., and Snell, Scott A. 1988. External Control, Corporate Strategy, and Firm Performance in Research-Intensive Industries. Strategic Management Journal. 9(6):577-590.

Hirshleifer, D., Hsu, P-H. and Li, D. 2013. Innovative efficiency and stock returns. Journal of Financial Economics. 107(3):632-654.

Hirshleifer, D., and Thakor, A.V. 1992. Managerial reputation, project choice, and debt. Review of Financial Studies. 5:437-470.

Holmström, B. 1999. Managerial Incentive Problems: A Dynamic Perspective. The Review of Economic Studies. 66(1):169-182.

Hoskisson, R. E., Hitt, M.A., Johnson, R.A. and Grossman, W. 2002. Conflicting voices: The effects of institutional ownership heterogeneity and internal governance on corporate innovation strategies. Academy of Management Journal. 45(4):697-716.

Jensen, M.C. 1986. Agency costs of free cash flow, corporate finance, and takeovers. American Economic Review. 76:323-329.

Jensen, M.C. 1993. The modern industrial revolution, exit, and the failure of internal control systems. The Journal of Finance. 48(3):831-880.

Jensen, M.C., and Meckling, W.H. 1976. Theory of the firm: Managerial behaviour, agency costs and ownership structure. Journal of Financial Economics. 3:305-360.

Kosnik, D.R. 1990. Effects of Board Demography and Directors' Incentives on Corporate Greenmail Decisions. Academy of Management Journal. 33:129-150.

Kroll, M., Walters, B.A. and Le, S.A. 2007. The impact of board composition and top management team ownership structure on post-IPO performance in young entrepreneurial firms. Academy of Management Journal. 50(5):1198-1216.

Lane, P.J., Cannella, A.C., and Lubatkin, M.H. 1998. Agency problems as antecedents to unrelated mergers and diversification: Amihud and Lev reconsidered. Strategic Management Journal. 19:555-578.

Li, J., and Tang, Y. I. 2010. CEO hubris and firm risk taking in China: The moderating role of managerial discretion. Academy of Management Journal. 53(1):45-68. 
Liao, T.L., Lin, W.C. 2017. Corporate Governance, Product Market Competition, and the Wealth Effect of R\&D Spending Changes. Financial Management. 6(3): 717-742.

Mallette, P., and Fowler, K.L. 1992. Effects of board composition and stock ownership on the adoption of poison pills. Academy of Management Journal. 35:1010-1035.

Manso, G. 2011. Motivating Innovation. The Journal of Finance. 66(5): 1823-1860.

Matsunaga, S. R. 1995. The effects of financial reporting costs on the use of employee stock options. Accounting Review. 70(1):1-26.

Mazzucato, M. 2013. Financing innovation: creative destruction vs. destructive creation. Industrial and Corporate Change. 22(4):851-867.

Mazzucato, M., and Tancioni, M. 2012. R\&D, patents and stock return volatility. Journal of Evolutionary Economics. 22(4):811-832.

McConnell J.J., and Servaes H. 1990. Additional evidence on equity ownership and corporate value. Journal of Financial Economics. 27:595-612.

Minetti, R., Murro, P. and Paiella, M. 2015. Ownership structure, governance, and innovation. European Economic Review. 80:165-193.

Mohnen, P., Mairesse, J., and Dagenais, M. 2006. Innovativity: A comparison across seven European countries. Economics of Innovation and New Technology. 15(4-5):391-413.

OECD. 2017. Science, Technology and Industry Scoreboard. OECD. Paris.

Perez, C. 2002. Technological revolutions and financial capital: the dynamics of bubbles and golden ages. Edward Elgar: Cheltenham.

Pfeffer, J., and Salancik, G.R. 1978. The external control of organizations: A resource dependence perspective. New York: Harper \& Row.

Polder, M., van Leeuwen, G., Mohnen, P. and Raymond, W. 2009. Productivity Effects of Innovation Modes. Amsterdam: Statistics Netherlands Working Paper 09033.

Qiu, B. 2017. Institutional Multiple Holdings and Corporate Innovation. Working paper. Missouri Western State University, Craig School of Business.

Romano, R. 2005. The Sarbanes-Oxley Act and the making of quack corporate governance. Yale Law Review. 114:1521-1611.

Serrasqueiro, Z., Maçãs Nunes, P., and Leitão, J. 2011. Sources of finance for R\&D investment: Empirical evidence from Portuguese SMEs using dynamic estimators. Innovation. 13:2, 187206.

Shiller, R.J. 2000. Irrational exuberance. Princeton University Press: Princeton.

Skinner, D.J. and Sloan, R.G. 2002. Earnings Surprises, Growth Expectations, and Stock Returns or Don't Let an Earnings Torpedo Sink Your Portfolio. Review of Accounting Studies. 7(2):289-312.

Sloan, R. G. 1993. Accounting earnings and top executive compensation. Journal of Accounting and Economics. 16(1):55-100.

Sundaramurthy, C. 1996. Corporate governance within the context of antitakeover provisions. Strategic Management Journal. 17:377-394.

Tylecote, A., and Visintin, F. 2008. Corporate Governance, Finance, and the Technological Advantage of Nations. Routledge: London.

Yang, H., 2016, Institutional Dual Holdings and Risk Shifting: Evidence from Corporate Innovation. 


\section{Table 1: Variables' definition}

\begin{tabular}{|c|c|}
\hline $\mathrm{R} \& \mathrm{D}$ & $\mathrm{R} \& \mathrm{D}$ expense from Compustat \\
\hline No. of patents filed & From professor Hall's website: https://eml.berkeley.edu/ bhhall/ \\
\hline Size: Total Assets & Natural log of Total Assets \\
\hline Leverage & Total debt divided by common equity \\
\hline $\begin{array}{l}\text { Capital Expenditures } \\
\text { to TA (CapEx/TA) }\end{array}$ & $\begin{array}{l}\text { Earnings after tax plus depreciation less working capital and less capital } \\
\text { expenditures divided by Total Assets }\end{array}$ \\
\hline Free Cash Flow (FCF) & $\begin{array}{l}\text { Free Cash Flow defined as net income plus depreciation, less working capital and } \\
\text { less capital expenditures }\end{array}$ \\
\hline $\begin{array}{l}\text { Market to Book Ratio } \\
\text { (M/B) }\end{array}$ & Market value of equity divided by book value of equity \\
\hline ROA & Net income divided by Total Assets \\
\hline $\begin{array}{l}\text { Industry Competition } \\
\text { (HHI) }\end{array}$ & Herfindahl-Hirschman Index measure of market concentration \\
\hline $\begin{array}{l}\text { Ownership } \\
\text { Concentration }\end{array}$ & Institutional ownership concentration measure (ownership HHI) \\
\hline $\begin{array}{l}\text { No. Institutional } \\
\text { Owners (No. Inst.) }\end{array}$ & Total no. of institutional owners \\
\hline $\begin{array}{l}\text { Block Institutional } \\
\text { Ownership (Block } \\
\text { Inst.) }\end{array}$ & $\%$ held by total block institutional owners \\
\hline $\begin{array}{l}\text { Ownership of Top } 5 \\
\text { (Own Top5) }\end{array}$ & $\%$ held by largest 5 block institutional owners \\
\hline Board Size & Total Number of directors on board \\
\hline $\begin{array}{l}\text { Board Independence } \\
\text { (Indep. Dir.) }\end{array}$ & $\begin{array}{l}\text { Total number of independent board members divided by total number of board } \\
\text { members }\end{array}$ \\
\hline CEO Duality & Indicator equal to 1 if the $\mathrm{CEO}$ is also the chair of the board and zero otherwise \\
\hline Female $(\%)$ & $\%$ of females on the board \\
\hline Board Ownership & $\%$ ownership by board members as a group \\
\hline Board Age & Average age of board members \\
\hline No. Directorships & Average other directorships of board members \\
\hline $\begin{array}{l}\text { CEO Salary } \\
\text { (thousands) }\end{array}$ & Annual CEO salary for the year \\
\hline $\begin{array}{l}\text { CEO Incentive } \\
\text { Compensation (CEO } \\
\text { Inc. Comp.) }\end{array}$ & Total annual CEO compensation minus the salary all divided by total compensation \\
\hline $\begin{array}{l}\text { Salary Top } 5 \\
\text { (thousands) }\end{array}$ & Annual total salary the top 5 executives of the company for the year \\
\hline $\begin{array}{l}\text { Incentive } \\
\text { Compensation Top } 5\end{array}$ & $\begin{array}{l}\text { Total annual compensation for the top } 5 \text { executives of the company minus their total } \\
\text { salaries all divided by their total compensation }\end{array}$ \\
\hline
\end{tabular}


Table 2: Descriptive statistics

Panel A: Firm Characteristics

\begin{tabular}{|lcccrr|}
\hline & Mean & Median & Min & Max & N \\
\hline \hline R\&D (mil.) & 168.61 & 111.22 & 0.10 & 16,085 & 33,795 \\
No. of patents filed & 12.64 & 0.50 & 0.50 & 5,052 & 33,795 \\
Size: Total Assets (mil.) & $17,582.18$ & $2,077.34$ & 1.00 & $2,573,126$ & 33,795 \\
Leverage & 3.98 & 0.25 & $-1,934.74$ & 81,141 & 33,795 \\
Capital Expenditures (mil.) & 360.09 & 46.94 & -0.17 & 37,985 & 33,795 \\
Free Cash Flow (mil.) & -50.06 & -73.77 & $-73,720.00$ & 53,394 & 33,795 \\
Market to Book Ratio & 3.69 & 2.12 & $-1,107.25$ & 6,600 & 30,590 \\
ROA & 0.07 & 0.04 & -78.17 & 119 & 33,795 \\
Industry Competition & 0.20 & 0.13 & 0.02 & 1 & 25,991 \\
\hline
\end{tabular}

Panel B: Ownership Variables

\begin{tabular}{|lrrrrr|}
\hline Ownership Variables & Mean & Median & Min & Max & N \\
\hline \hline Ownership Concentration & 38.90 & 0.06 & 0.01 & 323.00 & 33,795 \\
No. Institutional Owners & 190.32 & 134.00 & 0.00 & $2,035.00$ & 33,795 \\
Block Institutional Ownership & 0.13 & 0.09 & 0.00 & 4.03 & 33,795 \\
Ownership of Top 5 (\%) & 0.21 & 0.23 & 0.00 & 2.15 & 33,795 \\
\hline
\end{tabular}

Panel C: Board Variables

\begin{tabular}{|lrcccr|}
\hline & Mean & Median & Min & Max & N \\
\hline \hline Board Size & 9.37 & 9.00 & 3.00 & 28.00 & 33,795 \\
Board Independence (\%) & 0.75 & 0.75 & 0.00 & 1.00 & 33,795 \\
CEO Duality & 0.11 & 0.11 & 0.00 & 1.00 & 33,795 \\
Female (\%) & 0.12 & 0.12 & 0.00 & 0.75 & 33,795 \\
Total Board Ownership (\%) & 0.03 & 0.08 & 0.08 & 0.99 & 33,795 \\
Board Age & 61.60 & 60.00 & 44.20 & 79.20 & 33,795 \\
No. Directorships & 0.85 & 0.85 & 0 & 7.00 & 33,795 \\
\hline
\end{tabular}

Panel D: Compensation Variables

\begin{tabular}{|lrrrrr|}
\hline & Mean & Median & Min & Max & N \\
\hline \hline CEO Salary (thousands) & 624.56 & 565.00 & 0.00 & $8,755.00$ & 33,795 \\
CEO Incentive Compensation & 0.55 & 0.63 & 0.00 & 1.00 & 33,795 \\
Salary Top 5 (thousands) & $1,946.85$ & $1,926.00$ & 0.00 & $27,246.42$ & 33,795 \\
Incentive Compensation Top 5 & 0.48 & 0.55 & 0.00 & 1.00 & 33,795 \\
\hline
\end{tabular}


Table 3: Tests in Difference in Means

Panel A: Firm Characteristics

\begin{tabular}{|c|c|c|c|c|c|c|c|}
\hline & \multicolumn{2}{|c|}{ Canada } & \multicolumn{2}{|c|}{ US } & \multirow[b]{2}{*}{ T-test } & \multirow[b]{2}{*}{ P-val } & \\
\hline & $\mathbf{N}$ & Mean & $\mathbf{N}$ & Mean & & & \\
\hline $\mathrm{R} \& \mathrm{D}$ & 5,111 & 21.53 & 28,864 & 194.82 & -19.120 & 0.000 & $* * *$ \\
\hline No. of Patents filed & 5,111 & 1.41 & 28,864 & 14.64 & -8.442 & 0.000 & $* * *$ \\
\hline Size: Total Assets & 5,111 & 18083.10 & 28,864 & 17492.93 & 0.412 & 0.681 & \\
\hline Leverage & 5,111 & 20.96 & 28,864 & 0.95 & 2.938 & 0.003 & $* * *$ \\
\hline Capital Expenditures & 5,111 & 358.61 & 28,864 & 360.36 & -0.085 & 0.932 & \\
\hline Free Cash Flow & 5,111 & 50.17 & 28,864 & -67.92 & 3.011 & 0.003 & $* * *$ \\
\hline Market to Book Ratio & 5,111 & 4.43 & 28,864 & 3.56 & 0.851 & 0.395 & \\
\hline $\mathrm{ROA}$ & 5,111 & 0.04 & 28,864 & 0.08 & -3.038 & 0.002 & $* * *$ \\
\hline Industry Competition & 5,111 & 245.00 & 28,864 & 25746.00 & -0.093 & 0.926 & \\
\hline
\end{tabular}

Panel B: Ownership Variables

\begin{tabular}{|c|c|c|c|c|c|c|c|}
\hline & \multicolumn{2}{|c|}{ Canada } & \multicolumn{2}{|c|}{ US } & \multirow[b]{2}{*}{ T-test } & \multirow[b]{2}{*}{ P-val } & \\
\hline & $\mathbf{N}$ & Mean & $\mathbf{N}$ & Mean & & & \\
\hline Ownership Concentration & 5,111 & 0.253 & 28,684 & 0.046 & 88.657 & 0.000 & *** \\
\hline No. Institutional Owners & 5,111 & 88.657 & 28,684 & 215.031 & -54.438 & 0.000 & $* * *$ \\
\hline Block Institutional Ownership & 5,111 & 0.028 & 28,684 & 0.148 & -57.273 & 0.000 & **** \\
\hline Ownership of Top 5 & 5,111 & 0.060 & 28,684 & 0.233 & -86.352 & 0.000 & **** \\
\hline
\end{tabular}

Panel C: Board Variables

\begin{tabular}{|c|c|c|c|c|c|c|c|}
\hline & \multicolumn{2}{|c|}{ Canada } & \multicolumn{2}{|c|}{ US } & \multirow[b]{2}{*}{ T-test } & \multirow[b]{2}{*}{ P-val } & \\
\hline & $\mathbf{N}$ & Mean & $\mathbf{N}$ & Mean & & & \\
\hline Board Size & 5,111 & 9.000 & 28,684 & 9.444 & -17.224 & 0.000 & $* * *$ \\
\hline Board Independence & 5,111 & 0.750 & 28,684 & 0.747 & 1.763 & 0.078 & $*$ \\
\hline CEO Duality & 5,111 & 0.111 & 28,684 & 0.111 & -0.009 & 0.993 & \\
\hline Female $(\%)$ & 5,111 & 0.124 & 28,684 & 0.124 & -0.293 & 0.769 & \\
\hline Total Board Ownership & 5,111 & 0.076 & 28,684 & 0.092 & -0.169 & 0.085 & * \\
\hline Board Age & 5,111 & 61.600 & 28,684 & 61.627 & -0.716 & 0.474 & \\
\hline No. Directorships & 5,111 & 0.850 & 28,684 & 0.850 & -0.014 & 0.989 & \\
\hline
\end{tabular}

Panel D: Compensation Variables

\begin{tabular}{|lcr|rr|rrr|}
\hline \multicolumn{7}{c|}{ Canada } & \multicolumn{3}{c|}{ US } & & \\
\hline \hline \\
\hline CEO Salary & N & Mean & N & Mean & T-test & P-val & \\
CEO Incentive Compensation & 5,111 & 531.75 & 28,684 & 641.10 & -16.21 & $0.000^{* * *}$ \\
Salary Top 5 & 5,111 & 0.52 & 28,684 & 0.56 & -7.69 & $0.000^{* * *}$ \\
Incentive Compensation Top 5 & 5,111 & 203.82 & 28,684 & $2,257.43$ & -110.00 & $0.000^{* * *}$ \\
\hline
\end{tabular}


Table 4: VIF Tests of Main Variables in the Study

\begin{tabular}{|l|r|r|}
\hline \multicolumn{1}{|c|}{ Variable } & \multicolumn{1}{|c|}{ VIF } & \multicolumn{1}{|c|}{ 1/VIF } \\
\hline No. Institutional Owners (ln) & 5.75 & 0.1738 \\
\hline Size: Total Assets (ln) & 5.29 & 0.1889 \\
\hline Block Institutional Ownership & 4.53 & 0.2207 \\
\hline Ownership of Top 5 & 4.48 & 0.2233 \\
\hline Market to Book Ratio & 1.76 & 0.5686 \\
\hline US Indicator & 1.48 & 0.6746 \\
\hline Ownership Concentration & 1.46 & 0.6870 \\
\hline CEO Incentive Compensation & 1.41 & 0.7095 \\
\hline Board Independence & 1.39 & 0.7181 \\
\hline Board Size & 1.39 & 0.7183 \\
\hline CEO Salary (ln) & 1.38 & 0.7232 \\
\hline Total Board Ownership & 1.2 & 0.8324 \\
\hline No. Directorships (ln) & 1.2 & 0.8359 \\
\hline Female (\%) & 1.2 & 0.8362 \\
\hline ROA & 1.15 & 0.8731 \\
\hline Board Age & 1.09 & 0.9135 \\
\hline Recession 1 & 1.07 & 0.9302 \\
\hline Industry Competition (HHI) & 1.07 & 0.9378 \\
\hline Capital Expenditures to TA & 1.06 & 0.9428 \\
\hline Leverage & 1.04 & 0.9590 \\
\hline Recession 2 & 1.04 & 0.964 \\
\hline Free Cash Flow & 1.03 & 0.9671 \\
\hline CEO Duality & 1.01 & 0.9856 \\
\hline & 1.89 & \\
\hline Mean VIF & & \\
\hline & & \\
\hline
\end{tabular}


Table 5: Correlation Matrix of Main Variables in the Study

\begin{tabular}{|c|c|c|c|c|c|c|c|c|c|c|c|c|c|c|}
\hline & (1) & (2) & (3) & (4) & (5) & (6) & (7) & (8) & (9) & (10) & (11) & (12) & (13) & (14) \\
\hline (1) R\&D & 1 & & & & & & & & & & & & & \\
\hline (2) Log of Total Assets & 0.3038 & 1 & & & & & & & & & & & & \\
\hline (3) Leverage & 0.0012 & 0.0065 & 1 & & & & & & & & & & & \\
\hline (4) Capital Expenditures to TA & -0.027 & -0.0996 & -0.0056 & 1 & & & & & & & & & & \\
\hline (5) Free Cash Flow & -0.2856 & 0.0727 & 0.0044 & -0.0477 & 1 & & & & & & & & & \\
\hline (6) Market to Book Ratio & 0.11 & -0.0405 & 0.1388 & 0.0622 & -0.0073 & 1 & & & & & & & & \\
\hline (7) ROA & 0.058 & 0.0324 & -0.0202 & 0.0747 & -0.0159 & 0.2865 & 1 & & & & & & & \\
\hline (8) Industry Competition (HHI) & -0.0137 & -0.1666 & 0.001 & -0.042 & 0.0206 & 0.1025 & 0.0477 & 1 & & & & & & \\
\hline (9) Ownership Concentration & -0.006 & -0.044 & -0.0007 & -0.0055 & -0.0008 & -0.0016 & -0.0741 & 0.0097 & 1 & & & & & \\
\hline (10) No. Institutional Owners & 0.3617 & 0.7818 & -0.0027 & 0.0038 & -0.0076 & 0.3276 & 0.2175 & -0.0675 & -0.1318 & 1 & & & & \\
\hline (11) Block Institutional Ownership & -0.1298 & -0.3585 & 0.0087 & 0.0599 & -0.0205 & -0.0773 & -0.038 & 0.1116 & -0.0632 & -0.2883 & 1 & & & \\
\hline (12) Ownership of Top 5 & -0.1433 & -0.2918 & 0.0089 & 0.0022 & -0.0234 & -0.0996 & -0.0465 & 0.0803 & -0.1369 & -0.2421 & 0.8689 & 1 & & \\
\hline (13) Board Size & 0.143 & 0.488 & -0.0022 & -0.0717 & 0.0782 & -0.0171 & -0.0059 & -0.0625 & -0.0099 & 0.3504 & -0.2291 & -0.2143 & 1 & \\
\hline (14) Board Independence & 0.0728 & 0.1909 & 0.0148 & -0.0281 & -0.008 & 0.004 & -0.013 & 0.001 & 0.002 & 0.2139 & 0.0532 & 0.061 & 0.1566 & 1 \\
\hline
\end{tabular}


Table 6: R\&D Models - Full Sample

This table presents coefficients and p-values (in parentheses) of an OLS model of R\&D Expense of a sample of Canadian and U.S. firms. The dependent variable is the natural $\log$ of R\&D. U.S. is an indicator variable taking the value of 1 if the firm is incorporated in the U.S. and zero otherwise. 2000 Recess. and 2008 Recess. are indicators taking the value of 1 if year is 2000 and 2008, respectively. Control variables include: Size, Leverage, CapEx/TA, FCF, M/B, ROA, HHI, Own. Conc., No. Inst., Block Inst., Own Top5, Board Size, Indep. Dir, CEO Duality, Board Females, Board Own, Dir. Age, No. Directorships, CEO Salary, CEO Incentives. All variables are defined in Table 1. All models include Stock Exchange, Industry and Year Fixed Effects.

\begin{tabular}{|c|c|c|c|c|c|}
\hline & Model 1 & Model 2 & Model 3 & Model 4 & Model 5 \\
\hline US & $\begin{array}{c}-0.0854 \\
(0.440)\end{array}$ & $\begin{array}{c}-0.716^{\text {**** }} \\
(0.000)\end{array}$ & $\begin{array}{c}-0.0564 \\
(0.611)\end{array}$ & $\begin{array}{l}-0.0868 \\
(0.457)\end{array}$ & $\begin{array}{c}-0.686^{* * *} \\
(0.000)\end{array}$ \\
\hline 2000 Recession & $\begin{array}{l}0.0623 \\
(0.285)\end{array}$ & $\begin{array}{c}-0.0164 \\
(0.796)\end{array}$ & $\begin{array}{l}0.0491 \\
(0.411)\end{array}$ & $\begin{array}{l}0.0525 \\
(0.372)\end{array}$ & $\begin{array}{c}-0.0420 \\
(0.527)\end{array}$ \\
\hline 2008 Recession & $\begin{array}{l}0.198^{* * * *} \\
(0.001)\end{array}$ & $\begin{array}{l}-0.124 \\
(0.061)\end{array}$ & $\begin{array}{l}0.164^{* *} \\
(0.008)\end{array}$ & $\begin{array}{l}0.164^{* *} \\
(0.009)\end{array}$ & $\begin{array}{l}-0.103 \\
(0.151)\end{array}$ \\
\hline Size: Total Assets & $\begin{array}{l}0.443^{\text {**** }} \\
(0.000)\end{array}$ & $\begin{array}{c}0.00101 \\
(0.953)\end{array}$ & $\begin{array}{l}0.421^{* * * *} \\
(0.000)\end{array}$ & $\begin{array}{l}0.441^{* * *} \\
(0.000)\end{array}$ & $\begin{array}{c}0.000266 \\
(0.988)\end{array}$ \\
\hline Leverage & $\begin{array}{c}-0.00219^{* * *} \\
(0.000)\end{array}$ & $\begin{array}{c}-0.000578 \\
(0.136)\end{array}$ & $\begin{array}{c}-0.00209^{* * *} \\
(0.000)\end{array}$ & $\begin{array}{c}-0.00222^{* * *} \\
(0.000)\end{array}$ & $\begin{array}{c}-0.000647 \\
(0.096)\end{array}$ \\
\hline CapEx/TA & $\begin{array}{c}-2.619^{* * *} \\
(0.000)\end{array}$ & $\begin{array}{c}-2.909^{* * *} \\
(0.000)\end{array}$ & $\begin{array}{c}-2.611^{* * *} \\
(0.000)\end{array}$ & $\begin{array}{c}-2.638^{* * *} \\
(0.000)\end{array}$ & $\begin{array}{c}-2.917^{* * *} \\
(0.000)\end{array}$ \\
\hline FCF & $\begin{array}{c}-5.567^{\text {*** }} \\
(0.000)\end{array}$ & $\begin{array}{c}-4.950^{* * *} \\
(0.000)\end{array}$ & $\begin{array}{c}-5.464^{* * *} \\
(0.000)\end{array}$ & $\begin{array}{l}-5.301^{* * * *} \\
(0.000)\end{array}$ & $\begin{array}{c}-4.626^{* * *} \\
(0.000)\end{array}$ \\
\hline $\mathrm{M} / \mathrm{B}$ & $\begin{array}{l}0.566^{* * * *} \\
(0.000)\end{array}$ & $\begin{array}{l}0.260^{* * * *} \\
(0.000)\end{array}$ & $\begin{array}{l}0.543^{* * * *} \\
(0.000)\end{array}$ & $\begin{array}{l}0.572^{* * * *} \\
(0.000)\end{array}$ & $\begin{array}{c}0.267^{* * *} \\
(0.000)\end{array}$ \\
\hline ROA & $\begin{array}{l}-0.296^{* *} \\
(0.001)\end{array}$ & $\begin{array}{c}-0.686^{* * *} \\
(0.000)\end{array}$ & $\begin{array}{l}-0.236^{* *} \\
(0.010)\end{array}$ & $\begin{array}{c}-0.319^{* * *} \\
(0.000)\end{array}$ & $\begin{array}{c}-0.622^{* * *} \\
(0.000)\end{array}$ \\
\hline $\mathrm{HHI}$ & $\begin{array}{c}-0.206^{\text {**** }} \\
(0.001)\end{array}$ & $\begin{array}{l}-0.133^{*} \\
(0.036)\end{array}$ & $\begin{array}{l}-0.190^{* *} \\
(0.002)\end{array}$ & $\begin{array}{c}-0.202^{* * * *} \\
(0.001)\end{array}$ & $\begin{array}{c}-0.0904 \\
(0.164)\end{array}$ \\
\hline Own. Concen. & & $\begin{array}{l}0.004^{* * *} \\
(0.000)\end{array}$ & & & $\begin{array}{r}0.00349^{* * *} \\
(0.000)\end{array}$ \\
\hline No. Inst. & & $\begin{array}{l}1.219^{* * *} \\
(0.000)\end{array}$ & & & $\begin{array}{c}1.171^{* * *} \\
(0.000)\end{array}$ \\
\hline Block Inst. & & $\begin{array}{l}0.958^{* * *} \\
(0.000)\end{array}$ & & & $\begin{array}{c}0.873^{* * *} \\
(0.000)\end{array}$ \\
\hline
\end{tabular}




\begin{tabular}{|c|c|c|c|c|c|}
\hline & Model 2 & Model 2 & Model 3 & Model 4 & Model 5 \\
\hline Own Top5 & & $\begin{array}{l}-0.853^{\text {*** }} \\
(0.001)\end{array}$ & & & $\begin{array}{l}-0.896^{* * *} \\
(0.001)\end{array}$ \\
\hline Board Size & & & $\begin{array}{l}-0.131 \\
(0.051)\end{array}$ & & $\begin{array}{l}-0.0369 \\
(0.592)\end{array}$ \\
\hline Indep. Dir. & & & $\begin{array}{l}0.504^{* * *} \\
(0.000)\end{array}$ & & $\begin{array}{l}0.571^{* * *} \\
(0.000)\end{array}$ \\
\hline CEO Duality & & & $\begin{array}{l}-0.114^{*} \\
(0.013)\end{array}$ & & $\begin{array}{l}-0.109^{*} \\
(0.019)\end{array}$ \\
\hline Female $(\%)$ & & & $\begin{array}{l}0.761^{* * *} \\
(0.000)\end{array}$ & & $\begin{array}{l}0.539^{* *} \\
(0.002)\end{array}$ \\
\hline $\begin{array}{l}\text { Board Ownership } \\
(\%)\end{array}$ & & & $\begin{array}{c}-0.850^{* * *} \\
(0.000)\end{array}$ & & $\begin{array}{c}-0.364^{* *} \\
(0.002)\end{array}$ \\
\hline Board Age & & & $\begin{array}{c}-1.759^{* * *} \\
(0.000)\end{array}$ & & $\begin{array}{c}-1.548^{* * *} \\
(0.000)\end{array}$ \\
\hline No. Directorships & & & $\begin{array}{l}0.117^{* * * *} \\
(0.000)\end{array}$ & & $\begin{array}{c}0.0807^{* * * *} \\
(0.000)\end{array}$ \\
\hline CEO Salary & & & & $\begin{array}{l}-0.0286 \\
(0.153)\end{array}$ & $\begin{array}{l}-0.0139 \\
(0.517)\end{array}$ \\
\hline CEO Inc. Comp. & & & & $\begin{array}{l}0.101^{*} \\
(0.040)\end{array}$ & $\begin{array}{l}-0.102 \\
(0.170)\end{array}$ \\
\hline Constant & $\begin{array}{l}60.45^{* * *} \\
(0.000)\end{array}$ & $\begin{array}{l}51.47^{* * *} \\
(0.000)\end{array}$ & $\begin{array}{l}66.78^{* * * *} \\
(0.000)\end{array}$ & $\begin{array}{l}57.58^{* * *} \\
(0.000)\end{array}$ & $\begin{array}{l}54.34^{* * *} \\
(0.000)\end{array}$ \\
\hline Observations & 23659 & 20261 & 22947 & 23187 & 19183 \\
\hline Adjusted $R^{2}$ & 0.554 & 0.579 & 0.558 & 0.557 & 0.584 \\
\hline $\mathrm{F}$ & 544.2 & 489.5 & 475.0 & 532.1 & 415.8 \\
\hline Stock Exchange FE & yes & yes & yes & yes & yes \\
\hline Industry FE & yes & yes & yes & yes & yes \\
\hline Year FE & yes & yes & yes & yes & yes \\
\hline
\end{tabular}

$p$-values in parentheses

${ }^{*} p<0.05,{ }^{* *} p<0.01,{ }^{* * *} p<0.001$ 
Table 7: R\&D Models by Country - Canadian Firms

This table presents coefficients and p-values (in parentheses) of an OLS model of R\&D expense of the sub-sample of Canadian firms. The dependent variable is the natural $\log$ of R\&D. 2000 Recess. and 2008 Recess. are indicators taking the value of 1 if year is 2000 and 2008, respectively. Control variables include: Size, Leverage, CapEx/TA, FCF, M/B, ROA, HHI, Own. Conc., No. Inst., Block Inst., Own Top5, CEO Salary, CEO Incentives. All variables are defined in Table 1. All models include Stock Exchange, Industry and Year Fixed Effects.

\begin{tabular}{|c|c|c|c|c|c|}
\hline & Model 1 & Model 2 & Model 3 & Model 4 & Model 5 \\
\hline 2000 Recess. & $\begin{array}{l}0.0880 \\
(0.354)\end{array}$ & $\begin{array}{l}0.0588 \\
(0.531)\end{array}$ & $\begin{array}{l}0.0725 \\
(0.448)\end{array}$ & $\begin{array}{l}0.0991 \\
(0.296)\end{array}$ & $\begin{array}{l}0.0542 \\
(0.564)\end{array}$ \\
\hline 2008 Recess. & $\begin{array}{c}0.167 \\
(0.109)\end{array}$ & $\begin{array}{c}0.131 \\
(0.203)\end{array}$ & $\begin{array}{c}0.180 \\
(0.087)\end{array}$ & $\begin{array}{c}0.156 \\
(0.134)\end{array}$ & $\begin{array}{c}0.131 \\
(0.208)\end{array}$ \\
\hline Size: Total Assets & $\begin{array}{c}-0.00145 \\
(0.913)\end{array}$ & $\begin{array}{c}-0.0504^{* * *} \\
(0.001)\end{array}$ & $\begin{array}{c}0.00541 \\
(0.687)\end{array}$ & $\begin{array}{c}0.00898 \\
(0.510)\end{array}$ & $\begin{array}{c}-0.0330^{*} \\
(0.029)\end{array}$ \\
\hline Leverage & $\begin{array}{c}-0.000489^{* *} \\
(0.001)\end{array}$ & $\begin{array}{c}-0.000418^{* * *} \\
(0.004)\end{array}$ & $\begin{array}{c}-0.000460^{* *} \\
(0.002)\end{array}$ & $\begin{array}{c}-0.000519^{* * * *} \\
(0.000)\end{array}$ & $\begin{array}{c}-0.000418^{* * *} \\
(0.004)\end{array}$ \\
\hline CapEx/TA & $\begin{array}{c}-0.576^{* * *} \\
(0.000)\end{array}$ & $\begin{array}{c}-0.503^{* * *} \\
(0.000)\end{array}$ & $\begin{array}{c}-0.575^{* * *} \\
(0.000)\end{array}$ & $\begin{array}{c}-0.568^{* * *} \\
(0.000)\end{array}$ & $\begin{array}{c}-0.491^{* * *} \\
(0.000)\end{array}$ \\
\hline FCF & $\begin{array}{c}-5.279^{* * *} \\
(0.000)\end{array}$ & $\begin{array}{c}-4.608^{* * *} \\
(0.000)\end{array}$ & $\begin{array}{c}-5.355^{* * * *} \\
(0.000)\end{array}$ & $\begin{array}{c}-5.388^{* * *} \\
(0.000)\end{array}$ & $\begin{array}{c}-4.783^{* * *} \\
(0.000)\end{array}$ \\
\hline $\mathrm{M} / \mathrm{B}$ & $\begin{array}{c}0.357^{* * *} \\
(0.000)\end{array}$ & $\begin{array}{c}0.317^{* * *} \\
(0.000)\end{array}$ & $\begin{array}{c}0.335^{* * * *} \\
(0.000)\end{array}$ & $\begin{array}{c}0.367^{* * *} \\
(0.000)\end{array}$ & $\begin{array}{c}0.303^{* * *} \\
(0.000)\end{array}$ \\
\hline ROA & $\begin{array}{c}-0.735^{* * *} \\
(0.000)\end{array}$ & $\begin{array}{c}-0.637^{\text {**** }} \\
(0.000)\end{array}$ & $\begin{array}{c}-0.743^{* * *} \\
(0.000)\end{array}$ & $\begin{array}{c}-0.719^{* * *} \\
(0.000)\end{array}$ & $\begin{array}{c}-0.624^{\text {*** }} \\
(0.000)\end{array}$ \\
\hline HHI & $\begin{array}{c}-2.283^{* * *} \\
(0.000)\end{array}$ & $\begin{array}{c}-2.181^{* * *} \\
(0.000)\end{array}$ & $\begin{array}{c}-2.322^{* * *} \\
(0.000)\end{array}$ & $\begin{array}{c}-2.237^{* * *} \\
(0.000)\end{array}$ & $\begin{array}{c}-2.157^{* * *} \\
(0.000)\end{array}$ \\
\hline Own. Concen. & & $\begin{array}{c}0.00124^{* * *} \\
(0.000)\end{array}$ & & & $\begin{array}{c}0.00123^{* * *} \\
(0.000)\end{array}$ \\
\hline No. Inst. & & $\begin{array}{c}0.206^{* * *} \\
(0.000)\end{array}$ & & & $\begin{array}{c}0.210^{* * *} \\
(0.000)\end{array}$ \\
\hline Block Inst. & & $\begin{array}{c}3.498^{* * *} \\
(0.000)\end{array}$ & & & $\begin{array}{c}3.677^{* * * *} \\
(0.000)\end{array}$ \\
\hline Own Top5 & & $\begin{array}{c}-3.868^{* * *} \\
(0.000)\end{array}$ & & & $\begin{array}{c}-3.958^{* * *} \\
(0.000)\end{array}$ \\
\hline Board Size & & & $\begin{array}{l}-0.160 \\
(0.091)\end{array}$ & & $\begin{array}{l}-0.146 \\
(0.118)\end{array}$ \\
\hline Indep. Dir. & & & $\begin{array}{l}-0.0221 \\
(0.895)\end{array}$ & & $\begin{array}{l}0.0484 \\
(0.770)\end{array}$ \\
\hline
\end{tabular}




\begin{tabular}{|c|c|c|c|c|c|}
\hline & Model 1 & Model 2 & Model 3 & Model 4 & Model 5 \\
\hline CEO Duality & & & $\begin{array}{c}-0.0303 \\
(0.661)\end{array}$ & & $\begin{array}{r}-0.0145 \\
(0.831)\end{array}$ \\
\hline Female $(\%)$ & & & $\begin{array}{l}0.0964 \\
(0.702)\end{array}$ & & $\begin{array}{l}0.0281 \\
(0.910)\end{array}$ \\
\hline Board Ownership & & & $\begin{array}{c}0.300^{* * *} \\
(0.000)\end{array}$ & & $\begin{array}{c}0.320^{* * *} \\
(0.000)\end{array}$ \\
\hline Board Age & & & $\begin{array}{l}-0.193 \\
(0.622)\end{array}$ & & $\begin{array}{l}-0.132 \\
(0.732)\end{array}$ \\
\hline No. Directorships & & & $\begin{array}{l}0.0136 \\
(0.695)\end{array}$ & & $\begin{array}{c}0.00876 \\
(0.798)\end{array}$ \\
\hline CEO Salary & & & & $\begin{array}{c}0.00548 \\
(0.608)\end{array}$ & $\begin{array}{c}0.00403 \\
(0.703)\end{array}$ \\
\hline CEO Inc. Comp. & & & & $\begin{array}{c}-0.305^{* * *} \\
(0.000)\end{array}$ & $\begin{array}{c}-0.331^{\text {*** }} \\
(0.000)\end{array}$ \\
\hline Constant & $\begin{array}{c}58.66^{* * *} \\
(0.000)\end{array}$ & $\begin{array}{c}51.44^{* * * *} \\
(0.000)\end{array}$ & $\begin{array}{c}60.66^{* * * *} \\
(0.000)\end{array}$ & $\begin{array}{l}59.93^{* * * *} \\
(0.000)\end{array}$ & $\begin{array}{c}54.31^{* * * *} \\
(0.000)\end{array}$ \\
\hline Observations & 4,017 & 4,017 & 3,933 & 4,017 & 3,933 \\
\hline Adjusted $R^{2}$ & 0.307 & 0.325 & 0.312 & 0.310 & 0.336 \\
\hline $\mathrm{F}$ & 42.31 & 42.15 & 36.67 & 41.16 & 36.58 \\
\hline Industry FE & yes & yes & yes & yes & yes \\
\hline Year FE & yes & yes & yes & yes & yes \\
\hline
\end{tabular}

$p$-values in parentheses

${ }^{*} p<0.05,{ }^{* *} p<0.01,{ }^{* * *} p<0.001$ 
Table 8: R\&D Models by Country - U.S. Firms

This table presents coefficients and p-values (in parentheses) of an OLS model of R\&D expense of the sub-sample of U.S. firms. The dependent variable is the natural $\log$ of R\&D. 2000 Recess. and 2008 Recess. are indicators taking the value of 1 if year is 2000 and 2008, respectively. Control variables include: Size, Leverage, CapEx/TA, FCF, M/B, ROA, HHI, Own. Conc., No. Inst., Block Inst., Own Top5, CEO Salary, CEO Incentives. All variables are defined in Table 1. All models include Stock Exchange, Industry and Year Fixed Effects.

\begin{tabular}{|c|c|c|c|c|c|}
\hline 7 & Model 1 & Model 2 & Model 3 & Model 4 & Model 5 \\
\hline 2000 Recess. & $\begin{array}{l}0.0769 \\
(0.197)\end{array}$ & $\begin{array}{c}0.00376 \\
(0.954)\end{array}$ & $\begin{array}{l}0.0650 \\
(0.286)\end{array}$ & $\begin{array}{l}0.0734 \\
(0.220)\end{array}$ & $\begin{array}{l}-0.0169 \\
(0.803)\end{array}$ \\
\hline 2008 Recess. & $\begin{array}{l}0.316^{* * *} \\
(0.000)\end{array}$ & $\begin{array}{l}0.0394 \\
(0.559)\end{array}$ & $\begin{array}{l}0.294^{* * *} \\
(0.000)\end{array}$ & $\begin{array}{c}0.323^{* * *} \\
(0.000)\end{array}$ & $\begin{array}{c}0.117 \\
(0.108)\end{array}$ \\
\hline Size: Total Assets & $\begin{array}{l}0.372^{* * *} \\
(0.000)\end{array}$ & $\begin{array}{c}-0.177^{* * * *} \\
(0.000)\end{array}$ & $\begin{array}{l}0.357^{* * *} \\
(0.000)\end{array}$ & $\begin{array}{c}0.377^{* * *} \\
(0.000)\end{array}$ & $\begin{array}{c}-0.173^{* * *} \\
(0.000)\end{array}$ \\
\hline Leverage & $\begin{array}{c}-0.00222^{* * *} \\
(0.000)\end{array}$ & $\begin{array}{c}-0.000283 \\
(0.472)\end{array}$ & $\begin{array}{c}-0.00211^{* * *} \\
(0.000)\end{array}$ & $\begin{array}{c}-0.00227^{* * *} \\
(0.000)\end{array}$ & $\begin{array}{c}-0.000315 \\
(0.422)\end{array}$ \\
\hline CapEx/TA & $\begin{array}{c}-2.554^{* * *} \\
(0.000)\end{array}$ & $\begin{array}{c}-2.838^{* * *} \\
(0.000)\end{array}$ & $\begin{array}{c}-2.551^{* * *} \\
(0.000)\end{array}$ & $\begin{array}{c}-2.612^{* * *} \\
(0.000)\end{array}$ & $\begin{array}{c}-2.858^{* * *} \\
(0.000)\end{array}$ \\
\hline FCF & $\begin{array}{c}-5.969^{* * *} \\
(0.000)\end{array}$ & $\begin{array}{c}-5.216^{* * * *} \\
(0.000)\end{array}$ & $\begin{array}{c}-5.831^{* * *} \\
(0.000)\end{array}$ & $\begin{array}{c}-5.717^{* * *} \\
(0.000)\end{array}$ & $\begin{array}{c}-4.831^{* * *} \\
(0.000)\end{array}$ \\
\hline $\mathrm{M} / \mathrm{B}$ & $\begin{array}{l}0.594^{* * *} \\
(0.000)\end{array}$ & $\begin{array}{l}0.213^{* * *} \\
(0.000)\end{array}$ & $\begin{array}{l}0.572^{* * *} \\
(0.000)\end{array}$ & $\begin{array}{l}0.605^{* * *} \\
(0.000)\end{array}$ & $\begin{array}{l}0.215^{\text {*** }} \\
(0.000)\end{array}$ \\
\hline ROA & $\begin{array}{c}-0.327^{* * *} \\
(0.001)\end{array}$ & $\begin{array}{c}-0.771^{* * *} \\
(0.000)\end{array}$ & $\begin{array}{l}-0.263^{* *} \\
(0.006)\end{array}$ & $\begin{array}{c}-0.351^{* * *} \\
(0.000)\end{array}$ & $\begin{array}{c}-0.658^{* * *} \\
(0.000)\end{array}$ \\
\hline HHI & $\begin{array}{c}-0.384^{* * *} \\
(0.000)\end{array}$ & $\begin{array}{c}-0.339^{* * *} \\
(0.000)\end{array}$ & $\begin{array}{c}-0.351^{* * *} \\
(0.000)\end{array}$ & $\begin{array}{c}-0.385^{* * *} \\
(0.000)\end{array}$ & $\begin{array}{c}-0.278^{* * * *} \\
(0.000)\end{array}$ \\
\hline Own. Conc. & & $\begin{array}{l}5.211^{* * *} \\
(0.000)\end{array}$ & & & $\begin{array}{l}5.920^{* * *} \\
(0.000)\end{array}$ \\
\hline No. Inst. & & $\begin{array}{l}1.541^{* * *} \\
(0.000)\end{array}$ & & & $\begin{array}{l}1.529^{* * *} \\
(0.000)\end{array}$ \\
\hline Block Inst. & & $\begin{array}{l}1.222^{* * *} \\
(0.000)\end{array}$ & & & $\begin{array}{l}1.182^{* * * *} \\
(0.000)\end{array}$ \\
\hline Own Top5 & & $\begin{array}{c}-1.970^{* * *} \\
(0.000)\end{array}$ & & & $\begin{array}{c}-2.192^{* * *} \\
(0.000)\end{array}$ \\
\hline
\end{tabular}




\begin{tabular}{|c|c|c|c|c|c|}
\hline & Model 1 & Model 2 & Model 3 & Model 4 & Model 5 \\
\hline Board Size & & & $\begin{array}{c}-0.211^{* *} \\
(0.002)\end{array}$ & & $\begin{array}{l}-0.125 \\
(0.074)\end{array}$ \\
\hline Indep. Dir. & & & $\begin{array}{c}0.458^{* * *} \\
(0.000)\end{array}$ & & $\begin{array}{c}0.529^{* * *} \\
(0.000)\end{array}$ \\
\hline CEO Duality & & & $\begin{array}{c}-0.125^{* *} \\
(0.008)\end{array}$ & & $\begin{array}{l}-0.115^{*} \\
(0.015)\end{array}$ \\
\hline Female $(\%)$ & & & $\begin{array}{c}0.602^{* * *} \\
(0.001)\end{array}$ & & $\begin{array}{c}0.334 \\
(0.054)\end{array}$ \\
\hline Board Ownership & & & $\begin{array}{c}-0.904^{* * *} \\
(0.000)\end{array}$ & & $\begin{array}{c}-0.560^{* * *} \\
(0.000)\end{array}$ \\
\hline Board Age & & & $\begin{array}{c}-2.104^{* * *} \\
(0.000)\end{array}$ & & $\begin{array}{c}-1.982^{* * *} \\
(0.000)\end{array}$ \\
\hline No. Directorships & & & $\begin{array}{l}0.114^{* * * *} \\
(0.000)\end{array}$ & & $\begin{array}{c}0.0719^{* *} \\
(0.001)\end{array}$ \\
\hline CEO Salary & & & & $\begin{array}{c}-0.0671^{\text {**** }} \\
(0.001)\end{array}$ & $\begin{array}{r}-0.0357 \\
(0.100)\end{array}$ \\
\hline CEO Inc. Comp. & & & & $\begin{array}{c}0.000407 \\
(0.993)\end{array}$ & $\begin{array}{c}-0.205^{* * * *} \\
(0.000)\end{array}$ \\
\hline Constant & $\begin{array}{l}65.69^{* * *} \\
(0.000)\end{array}$ & $\begin{array}{c}53.67^{* * *} \\
(0.000)\end{array}$ & $\begin{array}{l}73.12^{* * * *} \\
(0.000)\end{array}$ & $\begin{array}{c}63.22^{* * *} \\
(0.000)\end{array}$ & $\begin{array}{c}57.78^{* * *} \\
(0.000)\end{array}$ \\
\hline Observations & 23,439 & 20,041 & 22,727 & 23,187 & 18,991 \\
\hline Adjusted $R^{2}$ & 0.539 & 0.568 & 0.544 & 0.541 & 0.575 \\
\hline $\mathrm{F}$ & 610.6 & 539.3 & 521.5 & 583.2 & 443.2 \\
\hline Industry FE & yes & yes & yes & yes & yes \\
\hline Year FE & yes & yes & yes & yes & yes \\
\hline
\end{tabular}




\section{Table 9 R\&D Models - Random Effects}

This table presents coefficients and p-values (in parentheses) of an OLS model of R\&D Expense of a sample of Canadian and U.S. firms. The dependent variable is the natural $\log$ of R\&D. U.S. is an indicator variable taking the value of 1 if the firm is incorporated in the U.S. and zero otherwise. 2000 Recess. and 2008 Recess. are indicators taking the value of 1 if year is 2000 and 2008, respectively. Control variables include: Size, Leverage, CapEx/TA, FCF, M/B, ROA, HHI, Own. Conc., No. Inst., Block Inst., Own Top5, Board Size, Indep. Dir, CEO Duality, Board Females, Board Own, Dir. Age, No. Directorships, CEO Salary, CEO Incentives. All variables are defined in Table 1. All models include Random Effects.

\begin{tabular}{|c|c|c|c|c|c|}
\hline & Model 1 & Model 2 & Model 3 & Model 4 & Model 5 \\
\hline US & $\begin{array}{c}0.330 \\
(0.078)\end{array}$ & $\begin{array}{l}-0.057 \\
(0.785)\end{array}$ & $\begin{array}{c}0.321 \\
(0.087)\end{array}$ & $\begin{array}{c}0.349 \\
(0.101)\end{array}$ & $\begin{array}{l}-0.011 \\
(0.961)\end{array}$ \\
\hline 2000 Recess. & $\begin{array}{l}-0.024 \\
(0.179)\end{array}$ & $\begin{array}{c}0.005 \\
(0.788)\end{array}$ & $\begin{array}{l}-0.019 \\
(0.308)\end{array}$ & $\begin{array}{r}-0.0338 \\
(0.093)\end{array}$ & $\begin{array}{l}0.0004 \\
(0.983)\end{array}$ \\
\hline 2008 Recess. & $\begin{array}{c}0.012 \\
(0.515)\end{array}$ & $\begin{array}{c}0.008 \\
(0.677)\end{array}$ & $\begin{array}{c}0.007 \\
(0.697)\end{array}$ & $\begin{array}{c}0.009 \\
(0.609)\end{array}$ & $\begin{array}{c}0.012 \\
(0.527)\end{array}$ \\
\hline Size & $\begin{array}{c}0.264^{* * *} \\
(0.000)\end{array}$ & $\begin{array}{c}0.118^{* * *} \\
(0.000)\end{array}$ & $\begin{array}{c}0.255^{\text {*** }} \\
(0.000)\end{array}$ & $\begin{array}{c}0.259^{* * * *} \\
(0.000)\end{array}$ & $\begin{array}{c}0.124^{* * *} \\
(0.000)\end{array}$ \\
\hline Leverage & $\begin{array}{l}0.0002 \\
(0.188)\end{array}$ & $\begin{array}{c}0.0004^{*} \\
(0.012)\end{array}$ & $\begin{array}{l}0.0002 \\
(0.188)\end{array}$ & $\begin{array}{c}0.0012^{\text {**** }} \\
(0.000)\end{array}$ & $\begin{array}{c}0.0004^{*} \\
(0.015)\end{array}$ \\
\hline CapEx/TA & $\begin{array}{c}0.119 \\
(0.414)\end{array}$ & $\begin{array}{l}-0.034 \\
(0.832)\end{array}$ & $\begin{array}{c}0.103 \\
(0.490)\end{array}$ & $\begin{array}{c}0.063 \\
(0.684)\end{array}$ & $\begin{array}{l}-0.080 \\
(0.619)\end{array}$ \\
\hline FCF & $\begin{array}{l}-0.244 \\
(0.115)\end{array}$ & $\begin{array}{c}-0.573^{* *} \\
(0.002)\end{array}$ & $\begin{array}{l}-0.251 \\
(0.108)\end{array}$ & $\begin{array}{l}-0.145 \\
(0.393)\end{array}$ & $\begin{array}{c}-0.493^{* *} \\
(0.008)\end{array}$ \\
\hline $\mathrm{M} / \mathrm{B}$ & $\begin{array}{c}0.079^{* * *} \\
(0.000)\end{array}$ & $\begin{array}{l}0.033^{* *} \\
(0.007)\end{array}$ & $\begin{array}{c}0.080^{* * * *} \\
(0.000)\end{array}$ & $\begin{array}{l}0.073^{* * *} \\
(0.000)\end{array}$ & $\begin{array}{c}0.044^{* * *} \\
(0.000)\end{array}$ \\
\hline ROA & $\begin{array}{l}0.095^{*} \\
(0.038)\end{array}$ & $\begin{array}{c}0.075 \\
(0.186)\end{array}$ & $\begin{array}{c}0.090 \\
(0.055)\end{array}$ & $\begin{array}{l}0.106^{*} \\
(0.035)\end{array}$ & $\begin{array}{c}0.059 \\
(0.291)\end{array}$ \\
\hline $\mathrm{HHI}$ & $\begin{array}{c}0.036 \\
(0.317)\end{array}$ & $\begin{array}{c}0.056 \\
(0.160)\end{array}$ & $\begin{array}{c}0.032 \\
(0.393)\end{array}$ & $\begin{array}{c}0.016 \\
(0.672)\end{array}$ & $\begin{array}{c}0.056 \\
(0.152)\end{array}$ \\
\hline Own. Concen. & & $\begin{array}{l}0.002^{* *} \\
(0.004)\end{array}$ & & & $\begin{array}{c}0.002^{* *} \\
(0.003)\end{array}$ \\
\hline No. Inst. & & $\begin{array}{c}0.305^{* * *} \\
(0.000)\end{array}$ & & & $\begin{array}{c}0.292^{* * *} \\
(0.000)\end{array}$ \\
\hline Block Inst. & & $\begin{array}{l}0.181^{*} \\
(0.027)\end{array}$ & & & $\begin{array}{c}0.141 \\
(0.087)\end{array}$ \\
\hline Own Top5 & & $\begin{array}{l}-0.024 \\
(0.861)\end{array}$ & & & $\begin{array}{l}-0.029 \\
(0.829)\end{array}$ \\
\hline
\end{tabular}


Board Size

Indep. Dir. (\%)

CEO Duality

Female (\%)

Board Ownership

Board Age

No. Directorships

CEO Salary

CEO Inc. Comp.
$-0.082$

(0.068)

$0.186^{* *}$

(0.004)

$-0.035$

(0.075)

$-0.191$

(0.068)

$-0.124$

(0.095)

$-0.069$

(0.658)

$0.029^{*}$

(0.043)
0.0125

(0.791)

0.131

(0.052)

$-0.034$

(0.091)

$-0.228^{*}$

(0.035)

$-0.142$

(0.089)

$-0.119$

(0.472)

$0.045^{* *}$

(0.003)

$\begin{array}{ll}-0.002 & -0.006\end{array}$

$(0.845) \quad(0.602)$

$0.054^{*} \quad 0.004$

(0.036) (0.859)

\begin{tabular}{lccccc} 
Constant & 1.755 & $5.350^{* *}$ & 2.301 & 0.698 & $4.926^{*}$ \\
& $(0.315)$ & $(0.010)$ & $(0.222)$ & $(0.716)$ & $(0.025)$ \\
\hline Observations & 23659 & 20261 & 22947 & 20936 & 19183 \\
$R^{2}$ - within & 0.0415 & 0.0524 & 0.0459 & 0.0374 & 0.0476 \\
$R^{2}$ - between & 0.0371 & 0.0034 & 0.0053 & 0.0364 & 0.0034 \\
$R^{2}$ - overall & 0.0554 & 0.0137 & 0.0189 & 0.0532 & 0.0146 \\
Walk Chi2 & 815.34 & 921.55 & 900.01 & 784.07 & 943.16 \\
\hline
\end{tabular}

$p$-values in parentheses

${ }^{*} p<0.05,{ }^{* *} p<0.01,{ }^{* * *} p<0.001$ 


\section{Table 10: Number of Patents Models}

This table presents coefficients and p-values (in parentheses) of an OLS model of No. of Patents of a sample of Canadian and U.S. firms. The dependent variable is the natural $\log$ of No. of Patents. U.S. is an indicator variable taking the value of 1 if the firms is incorporated in the U.S. and zero otherwise. 2000 Recess. and 2008 Recess. are indicators taking the value of 1 if year is 2000 and 2008, respectively. Control variables include: Size, Leverage, CapEx/TA, FCF, M/B, ROA, HHI, Own. Conc., No. Inst., Block Inst., Own Top5, Board Size, Indep. Dir, CEO Duality, Board Females, Board Own, Dir. Age, No. Directorships, CEO Salary, CEO Incentives. All variables are defined in Table 1. All models include Stock Exchange, Industry and Year Fixed Effects.

\begin{tabular}{|c|c|c|c|c|c|}
\hline 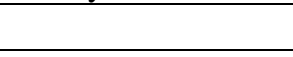 & Model 1 & Model 2 & Model 3 & Model 4 & Model 5 \\
\hline US & $\begin{array}{c}0.326^{* * *} \\
(0.000)\end{array}$ & $\begin{array}{c}0.120 \\
(0.250)\end{array}$ & $\begin{array}{c}0.353^{* * *} \\
(0.000)\end{array}$ & $\begin{array}{c}0.337^{* * * *} \\
(0.000)\end{array}$ & $\begin{array}{c}0.237^{*} \\
(0.036)\end{array}$ \\
\hline 2000 Recess. & $\begin{array}{l}-0.004 \\
(0.931)\end{array}$ & $\begin{array}{c}-0.0652 \\
(0.205)\end{array}$ & $\begin{array}{l}-0.0133 \\
(0.780)\end{array}$ & $\begin{array}{c}-0.00150 \\
(0.975)\end{array}$ & $\begin{array}{r}-0.0705 \\
(0.188)\end{array}$ \\
\hline 2008 Recess. & $\begin{array}{r}-0.0897 \\
(0.061)\end{array}$ & $\begin{array}{c}-0.258^{* * *} \\
(0.000)\end{array}$ & $\begin{array}{c}-0.0994^{*} \\
(0.046)\end{array}$ & $\begin{array}{c}-0.0378 \\
(0.453)\end{array}$ & $\begin{array}{c}-0.151^{* *} \\
(0.010)\end{array}$ \\
\hline Size: Total Assets & $\begin{array}{c}0.292^{* * *} \\
(0.000)\end{array}$ & $\begin{array}{c}0.0446^{* *} \\
(0.002)\end{array}$ & $\begin{array}{c}0.273^{* * *} \\
(0.000)\end{array}$ & $\begin{array}{c}0.297^{* * * *} \\
(0.000)\end{array}$ & $\begin{array}{c}0.0427^{* *} \\
(0.006)\end{array}$ \\
\hline Leverage & $\begin{array}{c}-0.0009^{* *} \\
(0.004)\end{array}$ & $\begin{array}{c}-0.00001 \\
(0.960)\end{array}$ & $\begin{array}{c}-0.0008^{* *} \\
(0.008)\end{array}$ & $\begin{array}{c}-0.0009^{* *} \\
(0.003)\end{array}$ & $\begin{array}{c}-0.00005 \\
(0.862)\end{array}$ \\
\hline CapEx/TA & $\begin{array}{l}-0.272 \\
(0.163)\end{array}$ & $\begin{array}{l}-0.326 \\
(0.121)\end{array}$ & $\begin{array}{l}-0.226 \\
(0.253)\end{array}$ & $\begin{array}{l}-0.292 \\
(0.137)\end{array}$ & $\begin{array}{c}-0.294 \\
(0.173)\end{array}$ \\
\hline FCF & $\begin{array}{l}-0.533^{*} \\
(0.011)\end{array}$ & $\begin{array}{l}-0.114 \\
(0.624)\end{array}$ & $\begin{array}{l}-0.501^{*} \\
(0.018)\end{array}$ & $\begin{array}{l}-0.472^{*} \\
(0.028)\end{array}$ & $\begin{array}{r}-0.0782 \\
(0.743)\end{array}$ \\
\hline $\mathrm{M} / \mathrm{B}$ & $\begin{array}{c}0.243^{* * *} \\
(0.000)\end{array}$ & $\begin{array}{c}0.0666^{* * *} \\
(0.000)\end{array}$ & $\begin{array}{c}0.231^{* * *} \\
(0.000)\end{array}$ & $\begin{array}{c}0.250^{* * * *} \\
(0.000)\end{array}$ & $\begin{array}{c}0.0739^{* * *} \\
(0.000)\end{array}$ \\
\hline ROA & $\begin{array}{c}-0.570^{* * *} \\
(0.000)\end{array}$ & $\begin{array}{c}-0.759^{* * *} \\
(0.000)\end{array}$ & $\begin{array}{c}-0.505^{* * *} \\
(0.000)\end{array}$ & $\begin{array}{c}-0.553^{* * *} \\
(0.000)\end{array}$ & $\begin{array}{c}-0.612^{* * *} \\
(0.000)\end{array}$ \\
\hline $\mathrm{HHI}$ & $\begin{array}{l}-0.109^{*} \\
(0.022)\end{array}$ & $\begin{array}{l}-0.120^{*} \\
(0.020)\end{array}$ & $\begin{array}{c}-0.129^{* *} \\
(0.008)\end{array}$ & $\begin{array}{l}-0.104^{*} \\
(0.030)\end{array}$ & $\begin{array}{l}-0.127^{*} \\
(0.016)\end{array}$ \\
\hline Own. Conc. & & $\begin{array}{l}3.018^{* * *} \\
(0.000)\end{array}$ & & & $\begin{array}{c}3.502^{* * *} \\
(0.000)\end{array}$ \\
\hline No. Inst. & & $\begin{array}{l}0.702^{* * * *} \\
(0.000)\end{array}$ & & & $\begin{array}{c}0.674^{* * *} \\
(0.000)\end{array}$ \\
\hline Block Inst. (\%) & & $\begin{array}{l}0.351^{* *} \\
(0.009)\end{array}$ & & & $\begin{array}{l}0.375^{* *} \\
(0.007)\end{array}$ \\
\hline
\end{tabular}




\begin{tabular}{|c|c|c|c|c|c|}
\hline & Model 1 & Model 2 & Model 3 & Model 4 & Model 5 \\
\hline Own Top5 & & $\begin{array}{c}-0.568^{* *} \\
(0.009)\end{array}$ & & & $\begin{array}{c}-0.860^{* * * *} \\
(0.000)\end{array}$ \\
\hline Board Size & & & $\begin{array}{c}-0.0782 \\
(0.144)\end{array}$ & & $\begin{array}{l}-0.107 \\
(0.054)\end{array}$ \\
\hline Indep. Dir. & & & $\begin{array}{c}0.327^{* * *} \\
(0.001)\end{array}$ & & $\begin{array}{c}0.399^{* * * *} \\
(0.000)\end{array}$ \\
\hline CEO Duality & & & $\begin{array}{l}0.0685 \\
(0.064)\end{array}$ & & $\begin{array}{c}0.0741^{*} \\
(0.048)\end{array}$ \\
\hline Females $(\%)$ & & & $\begin{array}{c}0.204 \\
(0.136)\end{array}$ & & $\begin{array}{c}0.00959 \\
(0.945)\end{array}$ \\
\hline Board Ownership & & & $\begin{array}{c}-0.621^{* * *} \\
(0.000)\end{array}$ & & $\begin{array}{c}-0.508^{* * *} \\
(0.000)\end{array}$ \\
\hline Board Age & & & $\begin{array}{c}-1.529^{* * *} \\
(0.000)\end{array}$ & & $\begin{array}{c}-1.479^{* * *} \\
(0.000)\end{array}$ \\
\hline No. Directorships & & & $\begin{array}{c}0.132^{* * *} \\
(0.000)\end{array}$ & & $\begin{array}{c}0.118^{* * *} \\
(0.000)\end{array}$ \\
\hline CEO Salary & & & & $\begin{array}{c}0.006 \\
(0.691)\end{array}$ & $\begin{array}{c}0.018 \\
(0.291)\end{array}$ \\
\hline CEO Inc. Comp. & & & & $\begin{array}{c}-0.168^{* * *} \\
(0.000)\end{array}$ & $\begin{array}{c}-0.295^{* * *} \\
(0.000)\end{array}$ \\
\hline Constant & $\begin{array}{c}3.342 \\
(0.158) \\
\end{array}$ & $\begin{array}{c}-2.854 \\
(0.278) \\
\end{array}$ & $\begin{array}{c}9.458^{* * * *} \\
(0.000)\end{array}$ & $\begin{array}{c}2.644 \\
(0.274) \\
\end{array}$ & $\begin{array}{c}2.977 \\
(0.286) \\
\end{array}$ \\
\hline Observations & 23,659 & 20,201 & 22,947 & 23,187 & 19,127 \\
\hline Adjusted $R^{2}$ & 0.370 & 0.390 & 0.378 & 0.370 & 0.400 \\
\hline $\mathrm{F}$ & 257.9 & 227.8 & 230.1 & 249.0 & 197.0 \\
\hline Stock Exchange FE & yes & yes & yes & yes & yes \\
\hline Industry FE & yes & yes & yes & yes & yes \\
\hline Year FE & yes & yes & yes & yes & yes \\
\hline
\end{tabular}

$p$-values in parentheses

${ }^{*} p<0.05,{ }^{* *} p<0.01,{ }^{* * *} p<0.001$ 